\title{
Platydoras brachylecis, a new species of thorny catfish (Siluriformes: Doradidae) from northeastern Brazil
}

\author{
Nivaldo M. Piorski ${ }^{1}$, Julio C. Garavello², Mariangeles Arce H. ${ }^{3}$ and Mark H. Sabaj Pérez ${ }^{4}$
}

Platydoras brachylecis, new species, is described from coastal drainages of northeastern Brazil (Pindaré to Parnaíba rivers), and diagnosed from congeners by the unique combination of: pale yellow to white stripe beginning above orbits, continuing midlaterally on body and onto middle rays of caudal fin; skin in axil of each midlateral thorn without concentration of pigment forming small dark spot, midlateral scutes shallow (depth of $10^{\text {th }}$ scute $8.8-11.9 \%$ of SL), and midlateral scutes on caudal peduncle distinctly separated by strip of skin from middorsal and midventral caudal-peduncle plates. Three additional species of Platydoras are recognized as valid: P. armatulus (lower Orinoco, Amazon and Paraguay-Paraná drainages), P. costatus (coastal drainages of Suriname and French Guiana), and $P$. hancockii (upper Orinoco, Negro, Essequibo and Demerara drainages). The nominal species $P$. dentatus and $P$. helicophilus are tentatively treated as junior synonyms of $P$. costatus. A key to species of Platydoras is provided.

Platydoras brachylecis, espécie nova, é descrita para as drenagens costeiras do nordeste do Brasil (rios Pindaré a Parnaíba) e diagnosticada de suas congêneres pela exclusiva combinação dos seguintes caracteres: faixa amarelo-pálida a branco iniciando acima das órbitas, continuando médio-lateralmente sobre o corpo e atingindo os raios medianos da nadadeira caudal; pele das axilas dos espinhos médio-laterais sem concentração de pequenas pintas negras; escudos médio-laterais baixos (altura do décimo escudo 8.8-11.9\% do comprimento padrão) e escudos médio-laterais do pedúnculo caudal distintamente separados das placas médio-dorsais e médio-ventrais da mesma região por uma faixa de pele. Mais três espécies de Platydoras são reconhecidas como válidas: $P$. armatulus (distribuída pelas drenagens do baixo Orinoco, Amazônia e Paraguai-Paraná), $P$. costatus (drenagens costeiras do Suriname e Guiana Francesa) e P. hancockii (drenagens do Negro, Essequibo, Demerara e alto Orinoco). As espécies nominais $P$. dentatus e $P$. helicophilus são provisoriamente consideradas sinônimos juniores de $P$. costatus. Uma chave de identificação para as espécies do gênero Platydoras é apresentada.

Key words: striped raphael, Platydoras costatus, Platydoras dentatus, Platydoras hancockii, Platydoras helicophilus.

\section{Introduction}

Bleeker (1862:5) proposed the genus Platydoras (striped raphael catfishes) for the species Silurus costatus Linnaeus 1758 , and briefly noted its caudal peduncle with multiple scutes above and below, and elongate, granular lateral scutes. Bleeker (1863) provided a more complete description and expanded the genus to include Doras armatulus Valenciennes, 1840, described from the rio Paraná, Brazil, and questionably Doras dentatus Kner, 1855, described from Suriname. Later Bleeker (1864) synonymized $D$. dentatus with $P$. costatus and noted the "habitat" of this species as Suriname. Additional species placed in Platydoras by Sabaj \& Ferraris (2003) were Doras hancockii described by Valenciennes (in Cuvier \& Valenciennes, 1840) based on Hancock's (1828) Doras costata from the Demerara River, Guyana, and Doras helicophilus described by Günther (1868a, 1868b) from the Maroni River, Suriname.

\footnotetext{
${ }^{1}$ Departamento de Oceanografia e Limnologia, Universidade Federal do Maranhão, Campus do Bacanga, Avenida dos Portugueses, s/n, 65085-580 São Luís, MA, Brazil.piorski@ufma.br

${ }^{2}$ Departamento de Ecologia e Biologia Evolutiva da Universidade Federal de São Carlos, Rodovia Washington Luís km 235, 13.569-290 São Carlos, SP, Brazil.garavelo@power.ufscar.br

${ }^{3}$ Pontifícia Universidade Católica do Rio Grande do Sul, Museu de Ciências e Tecnologia, Laboratório de Ictiologia, Av. Ipiranga, 6681, Caixa Postal 1429, 90619-900 Porto Alegre, RS, Brazil. mariangelesarce@yahoo.com.ar

${ }^{4}$ The Academy of Natural Sciences, Department of Ichthyology, 1900 Benjamin Franklin Parkway, Philadelphia, PA 19103, USA. sabaj@acnatsci.org
} 
Sabaj \& Ferraris (2003) also referred the nominal species Mystus ascita Gronow (in Gray 1854) to Platydoras. This name, however, is permanently invalid, preoccupied by Mystus ascita Walbaum (1792). Mystus ascita can be traced back to a specific Latin polynomial (No. 177) and illustrations (Pl. 5, figs. 1 and 2) in a pre-Linnaean work by Gronow (under alternate spelling Gronovius) published in 1756 (date erroneously as 1754 in Sabaj \& Ferraris, 2003:464). Linnaeus (1758:306), in his description of Silurus costatus, explicitly referred to Gronow's "No. 177" and the illustrations, thereby establishing the latter as iconotypes. This tie is important to the identification of Silurus costatus, type species of Platydoras, as there are no known type specimens. Gronow (Gronovius, 1756) did not specify a locality for his "No. 177"; however, many other neotropical specimens in his collection originated from Suriname (for accounts of Gronovius collections see Wheeler, 1958, 1985, 1989).

Examination of extant types and ongoing studies by the two junior authors (MAH, MHSP) confirm the distinctiveness of three nominal species of Platydoras: P. armatulus (Paraguay-Paraná and portions of Amazon and Orinoco basins), P. costatus (Corantijn and Maroni basins), and $P$. hancockii (Negro, Essequibo, Demerara, and upper Orinoco basins). Doras dentatus Kner, 1855 and Doras helicophilus Günther, 1868b, both described from Suriname, the latter from the Maroni River, are tentatively considered junior synonyms of $P$. costatus based on: comparisons of their extant types and other Suriname specimens to Gronow's (Gronovius, 1756) description and illustrations of the Linnaean P. costatus, and the likelihood that the missing type(s) of $P$. costatus originated from Suriname. Independent work on Platydoras by the senior author (Piorski, 1997, 1999) uncovered a distinct, undescribed form from northeastern Brazil. The purpose of this study is to diagnose and describe this form as a new species of Platydoras.

\section{Material and Methods}

Measurements were made to the nearest $0.1 \mathrm{~mm}$ using dial or digital calipers $(\leq 180 \mathrm{~mm})$ or a beam compass $(>180$ $\mathrm{mm}$ ). This paper combines two studies conducted independently by two groups of authors using different methodologies for compiling and comparing morphometric data. As a result of this collaborative effort two sets of measurements were recorded separately: one for comparing the new species to Platydoras armatulus and nearby populations of Platydoras in the Tocantins and Xingu basins (Platydoras sp.) using a canonical variate analysis, and the second for presentation of standard morphometric data and broader comparisons among a larger set of specimens from throughout the range of Platydoras.

The first set of measurements (NMP, JCG) was obtained by the "trussnet" method (Strauss \& Bookstein, 1982) whereby anatomical points (landmarks) were selected and numbered for the lateral head and body " $\mathrm{A}$ " and dorsal head and nuchal shield "B" (see also Piorski, 1997). Morphometric variables in the lateral head and body "trussnet" (Fig. 1a) are: A1 (1-2) $=$ distance from posteriormost margin of mouth opening to tip of snout; A2 (1-3) = from posteriormost margin of mouth opening to anteriormost base of pectoral-fin spine; A3 (1-4) = from posteriormost margin of mouth opening to middorsal anterior margin of middle nuchal plate; A4 (2-3) = from tip of snout to anteriormost base of pectoral-fin spine; A5 (2-4) = distance from tip of snout to middorsal anterior margin of middle nuchal plate; A6 (3-4) = from anteriormost base of pectoral-fin spine to middorsal anterior margin of middle nuchal plate; A7 (3-5) = from anteriormost base of pectoral-fin spine to origin of pelvic-fin; A8 (3-6) = distance between anteriormost bases of pectoral-fin spine and dorsal-fin locking spine; A9 (4-5) = from middorsal anterior margin of middle nuchal plate to origin of pelvic fin; A10 (4-6) = from middorsal anterior margin of middle nuchal plate to anteriormost base of dorsalfin locking spine; A11 (5-6) = from origin of pelvic fin to anteriormost base of dorsal-fin locking spine; A12 (5-7) = distance between origins of pelvic and anal fins; A13 (5-8)= from origin of pelvic fin to posteriormost base of dorsal fin; A14 (6-7) = from anteriormost base of dorsal-fin locking spine to origin of anal fin; A15 (6-8) = length of dorsal-fin base; A16 $(7-8)=$ from posteriormost base of dorsal fin to origin of anal fin; A17 (7-9) = length of anal-fin base; A18 (7-10) = from origin of anal fin to posteriormost base of adipose fin; A19 (8$9)=$ from posteriormost base of dorsal fin to posteriormost base of anal fin; A20 (8-10) = distance between the posteriormost bases of dorsal and adipose fins; A21 (9-10)= distance between the posteriormost bases of anal and adipose fins; A22 (9-11) = from posteriormost base of anal fin to posterior margin of last lateral line scute; A23 (10-11) = from posteriormost base of adipose fin to posterior margin of last lateral line scute.

Morphometric variables in the dorsal head and nuchal shield "trussnet" (Fig. 1b) are: Bl (1-2) = transverse distance between posteriormost limits of paired limbs of posterior nuchal plate; B2 (1-4) = diagonal between right posteriormost and left anteriormost limits of posterior nuchal plate; B3 (2-4) $=$ lateral distance between anteriormost and posteriormost limits of left half of posterior nuchal plate; B4 (3-4) = transverse distance between anteriormost limits of paired limbs of posterior nuchal plate; B5 (3-6) = diagonal between right posteriormost and left anteriormost limits of middle nuchal plate; B6 (4-6) = lateral distance between anteriormost and posteriormost limits of left half of middle nuchal plate; B7 (56) $=$ transverse distance between paired anteriormost limits of middle nuchal plate; B8 (5-8) = diagonal between right anteriormost limit of middle nuchal plate and left intersection of opercle and posttemporal-supracleithrum; B9 (6-8) = lateral distance between left anteriormost limit of middle nuchal plate and left intersection of opercle and posttemporalsupracleithrum; B10 (7-8) = transverse distance between the posteriormost limits of paired opercles; B11 (7-10)= diagonal between right intersection of opercle and posttemporal- 

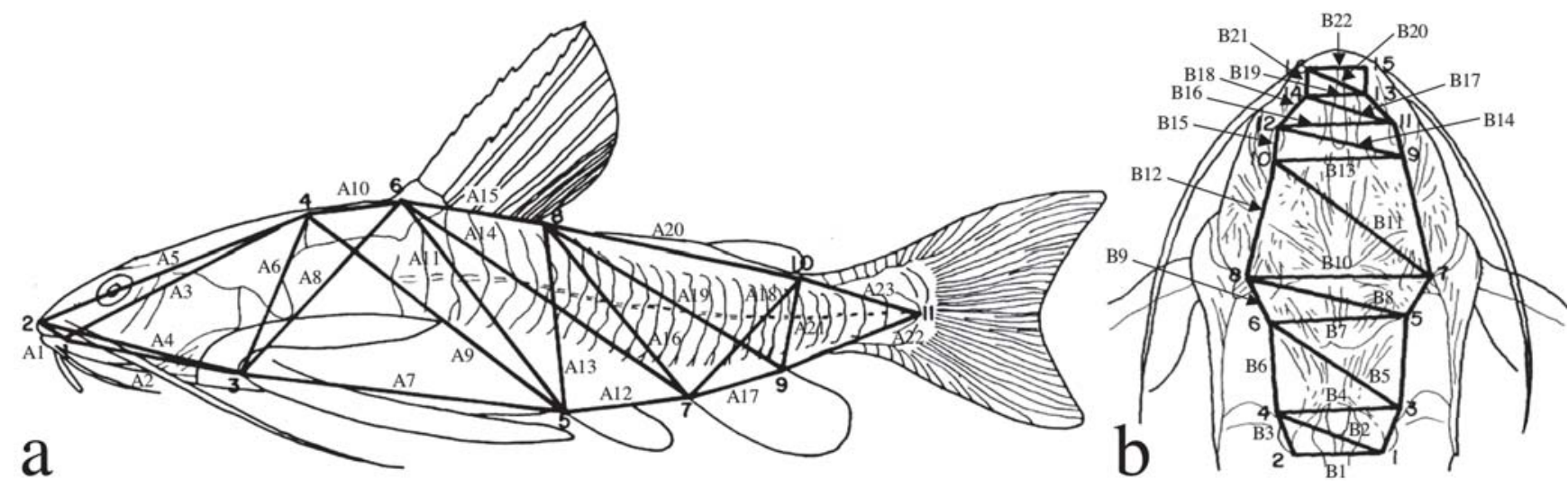

Fig. 1. Sets of anatomical landmarks (numbered) and distance measurements among them for trussnets of lateral head and body (A) and dorsal head and nuchal shield (B).

supracleithrum and left posteriormost limit of orbit; B12 (810) $=$ lateral distance between left posteriormost limit of orbit and left intersection of opercle and posttemporalsupracleithrum; B13 (9-10) = transverse distance between the posteriormost limits of paired orbits; B14 (9-12) = diagonal between right posterior and left anteriormost limits of paired orbits; B15 (10-12) = largest orbital diameter; B16 (11-12) = transverse distance between anteriormost limits of paired orbits; B17 (11-14) = diagonal between right anteriormost limit of orbit and left posterior nares; B18 (12-14) = lateral distance between anteriormost limit of left orbit and left posterior nares; B19 (13-14) = transverse distance between posterior nares; B20 (13-16) = diagonal between right posterior nares and left anterior nares; B21 (14-16) = lateral distance between the left anterior and posterior nares; B22 (15-16) = transverse distance between anterior nares.

The "trussnet" data were subjected to a size-free canonical variate analysis (SFCVA) using the statistical package SAS-PC (SAS Institute Inc.). Sixty-seven specimens (Table 1) were grouped accordingly: Platydoras armatulus (Paraguay-Paraná and Madeira basins; $\mathrm{n}=32$ ), P. brachylecis (Itapecuru-Mearim and Parnaíba basins; $\mathrm{n}=22$ ) and Platydoras sp. (Tocantins and Xingu basins; $\mathrm{n}=13$ ).

The second set of measurements (MAH, MHSP) represents point-to-point straight-line distances used in the species description with the following reported as percentages of standard length (SL), snout tip to posterior-most margin of hypural plate (midlateral point above and below which faint oblique creases follow bases of caudal-fin rays when caudal fin is gently flexed): head length $(\mathrm{HL})=$ snout tip to posteriormost extremity of fleshy opercular flap (also expressed as percentage of $\mathrm{PdD})$; predorsal distance $(\mathrm{PdD})=$ snout tip to posterior margin of middle nuchal plate coinciding with medial sagittal plane; snout-postcleithral process (SPcPD) = snout tip to distal-most tip of postcleithral (humeral) process; dorsal origin-posterior adipose distance $(\mathrm{DOAD})=$ from groove between medial posterior margin of middle nuchal plate (anterior to base of dorsal-locking spine) to posterior base of adipose fin; adipose-caudal distance $(\mathrm{AdCD})=$ posterior base of adipose fin to flexion point of hypural plate coinciding with posterior terminus of SL; prepectoral distance $(\mathrm{PpD})=$ snout tip to point between notch formed by margin of cleithrum and anterior base of erected (30-45 degrees) pectoral-fin spine; pectoral-pelvic distance (PPD) $=$ from anterior base of pectoral-fin spine (terminus of PpD) to base of first (anterior-most) pelvic-fin ray (best measured by abducting pelvic fin); pelvic-anal distance $(\mathrm{PAD})=$ from an-

Table 1. Loadings of variables on the first and second sizefree canonical variates for separate analyses of lateral and dorsal trussnets in Platydoras armatulus $(\mathrm{n}=32), P$. brachylecis, new species $(\mathrm{n}=22)$, and Platydoras $\mathrm{sp}$. Tocantins/Xingu $(\mathrm{n}=13) . * *=$ probability $(\mathrm{p}) \leq 0.01, * 0.01<$ $\mathrm{p} \leq 0.05, \mathrm{~ns}=$ not significant.

\begin{tabular}{|c|c|c|c|c|c|c|c|c|c|}
\hline \multicolumn{5}{|c|}{ Body trussnet } & \multicolumn{5}{|c|}{ Head trussnet } \\
\hline Variable & CV I & $\mathrm{p}$ & CV II & $\mathrm{p}$ & Variable & CV I & $\mathrm{p}$ & CV II & $\mathrm{p}$ \\
\hline A1 & -0.30 & * & 0.30 & * & B1 & 0.29 & * & -0.19 & ns \\
\hline A2 & -0.07 & ns & 0.08 & ns & B2 & -0.01 & ns & 0.24 & $*$ \\
\hline A3 & -0.25 & $*$ & 0.01 & ns & B3 & 0.12 & ns & 0.28 & * \\
\hline A4 & -0.14 & ns & 0.19 & ns & B4 & -0.31 & $* *$ & 0.15 & ns \\
\hline A5 & -0.23 & ns & -0.06 & ns & B5 & -0.42 & $* *$ & 0.23 & ns \\
\hline A6 & -0.49 & $* *$ & 0.25 & $*$ & B6 & 0.22 & $\mathrm{~ns}$ & -0.29 & * \\
\hline A7 & 0.41 & $* *$ & 0.01 & $\mathrm{~ns}$ & B7 & -0.31 & $* *$ & 0.42 & $* *$ \\
\hline A8 & -0.57 & $* *$ & 0.28 & $*$ & B8 & -0.59 & $* *$ & 0.24 & $*$ \\
\hline A9 & 0.35 & $* *$ & 0.05 & ns & B9 & -0.32 & $* *$ & -0.29 & * \\
\hline A 10 & 0.17 & $\mathrm{~ns}$ & -0.09 & $\mathrm{~ns}$ & B10 & -0.29 & $*$ & 0.31 & $* *$ \\
\hline A11 & 0.11 & ns & 0.15 & ns & B11 & -0.27 & $*$ & 0.56 & $* *$ \\
\hline A12 & 0.24 & $*$ & -0.17 & ns & $\mathrm{B} 12$ & 0.06 & $\mathrm{~ns}$ & 0.48 & $* *$ \\
\hline A13 & -0.11 & $\mathrm{~ns}$ & 0.09 & $\mathrm{~ns}$ & B13 & -0.40 & $* *$ & 0.40 & $* *$ \\
\hline A14 & 0.59 & $* *$ & -0.23 & ns & B14 & -0.58 & $* *$ & -0.16 & ns \\
\hline A 15 & 0.36 & $* *$ & -0.30 & $*$ & B15 & 0.12 & $\mathrm{~ns}$ & -0.77 & $* *$ \\
\hline A 16 & 0.51 & $* *$ & 0.19 & ns & B16 & -0.59 & $* *$ & -0.17 & ns \\
\hline A17 & 0.57 & $* *$ & -0.04 & $\mathrm{~ns}$ & B17 & -0.28 & $*$ & 0.07 & ns \\
\hline A 18 & 0.31 & $*$ & -0.39 & $* *$ & B18 & -0.43 & $* *$ & -0.27 & $*$ \\
\hline A19 & 0.68 & ** & -0.22 & $\mathrm{~ns}$ & B19 & 0.19 & $\mathrm{~ns}$ & -0.01 & ns \\
\hline $\mathrm{A} 20$ & 0.64 & $* *$ & -0.28 & $*$ & B20 & -0.24 & $*$ & 0.18 & ns \\
\hline A 21 & -0.40 & $* *$ & -0.25 & $*$ & B21 & 0.20 & $\mathrm{~ns}$ & -0.24 & $*$ \\
\hline A22 & 0.05 & $\mathrm{~ns}$ & 0.35 & $* *$ & B22 & -0.50 & $* *$ & 0.48 & $* *$ \\
\hline A23 & -0.01 & ns & 0.42 & $* *$ & & & & & \\
\hline
\end{tabular}


terior base of first pelvic-fin ray to anterior base of first analfin ray; anal-caudal distance $(\mathrm{AnCD})=$ from posterior base of posterior-most anal-fin ray to flexion point of hypural plate coinciding with posterior terminus of SL; dorsal-fin spine length $(\mathrm{DSL})=$ from groove between medial posterior margin of middle nuchal plate and base of dorsal locking spine to bony tip of erected (30-45 degrees) dorsal-fin spine excluding soft break-away tip if present; pectoral-fin spine length (PSL) $=$ from anterior base of erected (30-45 degrees) pectoral-fin spine to bony tip, excluding soft break-away tip if present; pelvic fin length $(\mathrm{PFL})=$ from anterior-most base of first ray to distal-most tip of fin (not the measurement of an individual ray); anal-fin base $(\mathrm{AnFB})=$ distance between anterior-most and posterior-most bases of anal-fin insertion; head width $(\mathrm{HW})=$ greatest transverse distance between lateral contours of opercula (opercula compressed to normal position if flared) anterior to cleithra (also expressed as percentage of $\mathrm{PdD}$ ); cleithral width $(\mathrm{CW})=$ greatest transverse distance between lateral contours of cleithra (also expressed as percentage of PdD); head depth (HD) = vertical depth in medial sagittal plane at middle pitline (transverse groove) across center of supraoccipital (also expressed as percentage of PdD); body depth $(\mathrm{BD})=$ vertical depth in medial sagittal plane between shallow crest of posterior margin of middle nuchal plate and midventral contour of body (also expressed as percentage of $\mathrm{PdD})$; caudal peduncle depth $(\mathrm{CPD})=$ least depth of caudal peduncle.

The following measurements are reported as percentages of predorsal distance: adipose eyelid diameter $(\mathrm{AED})=$ horizontal diameter of eye including thin adipose eyelid; orbital diameter (OD), diameter of bony concavity dorsally enclosing eye from posterior lateral corner of lateral ethmoid to point formed usually by anterior-most lateral corner of sphenotic or rarely by posterior lateral corner of frontal (line of measurement at slight angle to that of AED); snout-anterior nares distance $($ SAND $)=$ snout tip to center of opening of anterior nares; snout-posterior nares distance $(\mathrm{SPND})=$ snout tip to center of opening of posterior nares; snout-posterior orbit distance $(\mathrm{SPOD})=$ snout tip to posterior-most bony corner of orbital concavity (posterior terminus of OD); anterior naresposterior orbit distance $(A N P O D)=$ from center of opening of anterior nares to posterior-most bony corner of orbital concavity (posterior terminus of OD); posterior nares-posterior orbit distance $(\mathrm{PNPOD})=$ from center of opening of posterior nares to posterior-most bony corner of orbital concavity (posterior terminus of OD); internares distance (ID) = between centers of openings of anterior and posterior nares; postorbital length $(\mathrm{PL})=$ from posterior-most bony corner of orbital concavity (posterior terminus of OD) to posterior margin of middle nuchal plate in medial sagittal plane; postcleithral (humeral) process length $(\mathrm{PcPL})=$ from posterior-most tip to point along dorsal margin of exposed surface of process that is vertically aligned with posterior-most margin of fleshy opercle (exposed surface of postcleithral process appears slightly elevated and textured compared to smooth face of medially deflected portion of cleithrum lying beneath opercle); postcleithral (humeral) process depth $(\mathrm{PcPD})=$ greatest depth orthogonal to straight line formed by long axis of process (also expressed as percentage of PcPL); interorbital width (IW) $=$ shortest transverse distance between bony orbital margins of frontals.

Finally, two measurements are reported separately as percentages of SL and body depth taken in same transverse plane (adapted from Böhlke, 1970): depth of fifth (SD5) and tenth midlateral scutes $(\mathrm{SD} 10)=$ vertical depth orthogonal to horizontal line formed by medial thorns of scutes, from dorsal-most exposed margin of fifth (or tenth) plate to ventralmost margin of corresponding plate. The ratio of scute depth to SL is more consistent and reliable for comparisons between species because ratios of scute depth to body depth are strongly influenced by the contents of the gut (i.e., full vs. empty; compare standard deviations for ratios of scute depths in Table 2).

Counts of dorsal-, anal-, and paired-fin elements are separated into anterior spine (capital roman numeral) or unbranched soft ray (lower-case roman numeral) and posterior branched soft rays (arabic numerals). The small locking spine (spinelet) anterior to the dorsal-fin spine is counted. The last (posterior-most) pectoral-fin ray may appear unbranched, particularly in juveniles); it was counted if clearly segmented with its base separated from the penultimate ray. In rare instances the last pectoral-fin ray may be followed by a much smaller and rather inconspicuous sliver-like element that is clearly unsegmented; this bony element was not included in the count. The anterior-most anal-fin ray counted may be extremely small and closely adhered to the second ray. The last anal ray may be simple or composed of two branches with bases joined or in very close proximity (counted as one). Counts of midlateral scutes begin with the vertically expanded infranuchal scute that dorsally contacts the posterior nuchal plate, ventrally contacts or approaches the distal tip of the postcleithral process, and medially contacts the first rib, borne on the $6^{\text {th }}$ vertebra. Though conspicuous and sometimes bearing a medial thorn, the third scute in the tympanal region (immediately anterior to the infranuchal scute) was not included in counts of midlateral scutes.

Museum abbreviations follow Ferraris (2007) with the addition of LISDEBE for Laboratório de Ictiologia Sistemática do Departamento de Ecologia e Biologia Evolutiva da Universidade Federal de São Carlos, Brazil.

\section{Results}

In the SFCVA applied to both trussnets for lateral head and body and dorsal head and nuchal shield (Fig. 2) the first (CV1) and second (CV2) canonical variate axes explained $52.48 \%$ and $22.8 \%$ of the variance, respectively, between specimens of Platydoras armatulus (Paraguay-Paraná/Madeira; $\mathrm{n}=32$ ), . . brachylecis (Itapecuru-Mearim/Parnaíba; $\mathrm{n}$ 
$=22$ ) and Platydoras sp. (Tocantins/Xingu basins; $\mathrm{n}=13$ ).

Platydoras brachylecis was distinguished from both $P$. armatulus and Platydoras sp. on CV1, and Platydoras sp. was distinguished from both $P$. brachylecis and $P$. armatulus on CV2. Measurement variables distinguishing $P$. brachylecis by loading most heavily on CV1 (Table 1) are for the lateral trussnet (Fig. 1a), in decreasing magnitude: posteriormost base of dorsal fin to posteriormost base of anal fin (A19; longer in $P$. brachylecis), distance between the posteriormost bases of dorsal and adipose fins (A20; longer in $P$. brachylecis), and anteriormost base of dorsal-fin locking spine to origin of anal fin (A14; longer in P. brachylecis). Measurement variables loading most heavily on CV1 for the dorsal trussnet (Fig. 1b) are, in decreasing magnitude: diagonal between right anteriormost limit of middle nuchal plate and left intersection of opercle and posttemporal-supracleithrum (B8; shorter in $B$. brachylecis), transverse distance between anteriormost limits of paired orbits (B16; shorter in $B$. brachylecis), and diagonal between right posterior and left anteriormost limits of paired orbits (B14; shorter in $B$. brachylecis).

Measurement variables distinguishing Platydoras sp. by loading most heavily on CV2 (Table 1) are for the lateral trussnet, in decreasing magnitude: posteriormost base of adipose fin to posterior margin of last lateral line scute (A23; shorter in Platydoras sp.), origin of anal fin to posteriormost base of adipose fin (A18; longer in Platydoras sp.), posteriormost base of anal fin to posterior margin of last lateral line scute (A22; shorter in Platydoras sp.). Measurement variables loading most heavily on CV2 for the dorsal trussnet are, in decreasing magnitude: largest orbital diameter (B15; larger in Platydoras sp.), diagonal between right intersection of opercle and posttemporal-supracleithrum and left posteriormost limit of orbit (B11; shorter in Platydoras sp.), transverse distance between anterior nares (B22; shorter in Platydoras sp.) lateral distance between left posteriormost limit of orbit and left intersection of opercle and posttemporalsupracleithrum (B12; shorter in Platydoras sp.).

\section{Platydoras brachylecis, new species Figs. 3, 4}

Doras (Doras) costatus.—Eigenmann \& Eigenmann, 1888: 161 [in part, checklist with cited localities from Rio Puty (= Poti), ?Rio Preto, San Gonçallo (= São Gonçalo)]

Doras costatus. - Eigenmann \& Eigenmann, 1890: 231-234 [in part, same localities cited in Eigenmann \& Eigenmann, 1888].

Platydoras costatus.-Fowler, 1941: 139 [in part, three specimens from Forteleza, Ceará].-Fowler, 1951: 509-511 [in part, literature compilation with cited distribution in Ceará and Rio Poti].--Menezes \& Menezes, 1948 [gut length and contents in specimens from lagoa de Nazaré, Floriano, Piauí].-Sabaj \& Ferraris, 2003: 464 [in part, checklist with cited distribution in Parnaíba].- Soares, 2005: 91 [Mearim basin, photo, diet, habitat, common names, note on undescribed species from rio Pindaré].

Platydoras [sp.].-Piorski, 1999 [comment recognizing undescribed form from northeast Brazil].

Holotype. MZUSP 43593, 137.7 mm SL, Brazil, Maranhão, lago

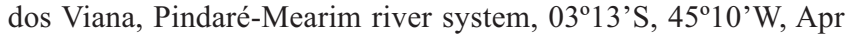
1984, B.V.O. Moura.

Paratypes. All Brazil. Ceará: ANSP 81733, 3, 180-197 mm SL, market at Fortaleza, 1937, R. von Ihering. Maranhão: LISDEBE 1969, 6, 91.1-112.6 mm SL, lago Açu, Pindaré basin, Codó market, 16 Feb 1994, N. M. Piorski; LISDEBE 1970, 19, 80.5-113.5 mm $\mathrm{SL}$, rio Itapecuru, Itapecuru-Mirim, 03⒉' ${ }^{\circ} \mathrm{S} 44^{\circ} 22^{\prime} \mathrm{W}, 18$ May 1996, Márvio and Lucemir; MCP 22532, 19, 21.5-49.8 mm SL, rio Peritoró, Peritoró Municipality, 04²2’23"S 44²0’07"W, 25 Jul 1998, R. E. Reis et al.; MNRJ 30919, 1, 171.5 mm SL, rio Itapecuru, Coroatá, no date, Departamento Nacional de Obras Contra a Seca; MZUSP 53240, 1, $150.3 \mathrm{~mm}$ SL and MZUSP 53241, 23, 107.2$151 \mathrm{~mm}$ SL, same data as LISDEBE 1970; MZUSP 53243, 5, 71.8$96.4 \mathrm{~mm} \mathrm{SL}$, same data as LISDEBE 1969; MZUSP 62674, 1, $123.9 \mathrm{~mm}$ SL, rio Itapecuru, Rosário, no date, Departamento Nacional de Obras Contra a Seca; MZUSP 62675, 1, 216 mm SL, rio Mearim, no date, Departamento Nacional de Obras Contra a Seca; MZUSP 100197, 5, 126.8-173 mm SL, same data as holotype. Piauí: AUM 28560, 2, 134-138.4 mm SL, rio Parnaíba, Barra do Longá, Buriti dos Lopes, 03¹0’30"S 4152’01"W, 26 Aug 1970, J.W. Bezerra et al.; ANSP 187051, 1, 179 mm SL, Mercado de Teresina, $05^{\circ} 05^{\prime}$ S 42 $48^{\prime} \mathrm{W}, 19-22$ Jun 1966, Expedição do Departamento de Zoologia; MZUSP 5122, 8, 94.7-127.3 mm SL, same data as ANSP 187051; NMW 46847, 2, 146.8-170 mm SL, rio Parnaíba, Teresina, 1903.

Diagnosis. Platydoras brachylecis is diagnosed among Platydoras by the following unique combination of characters: pale yellow to white stripe beginning above orbits, con-

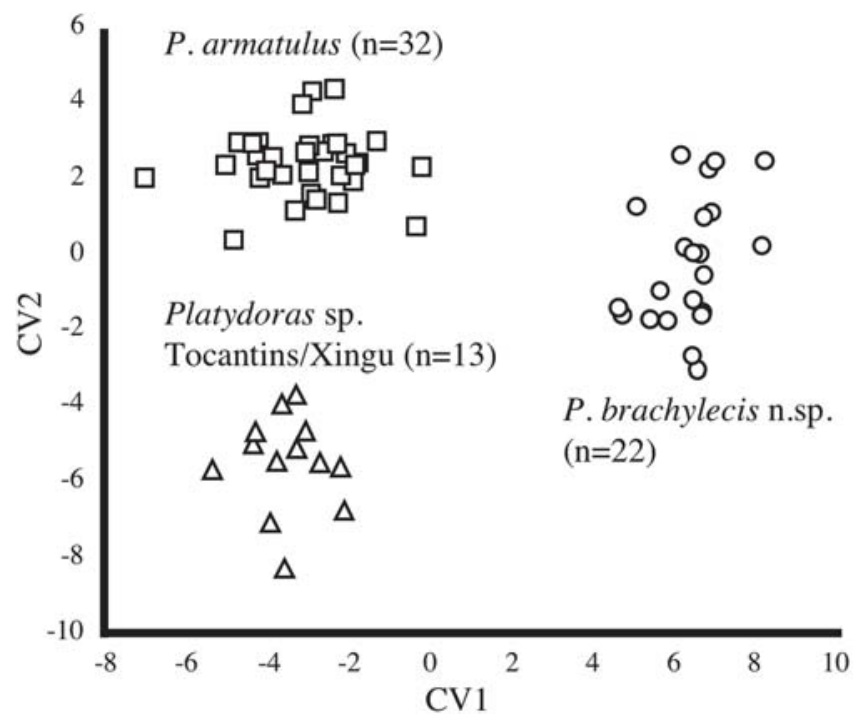

Fig. 2. Scatter plot of individual scores for three groups of Platydoras resulting from SFCVA of both lateral and dorsal trussnets. Canonical variate axes 1 and 2 explain $52.48 \%$ and $22.8 \%$ of the variance, respectively. 
tinuing midlaterally on body and onto middle rays of caudal fin; skin in axil of each midlateral thorn without concentration of pigment forming small dark spot; midlateral scutes shallow (depth of $10^{\text {th }}$ scute $8.8-11.9 \%$ of SL, $\mathrm{n}=15$ ); and midlateral scutes on caudal peduncle distinctly separated by strip of skin from middorsal and midventral caudal-peduncle plates (i.e., modified procurrent caudal-fin rays).

Platydoras costatus lacks the pale yellow to white midlateral stripe and has a small dark spot in the axil of each midlateral thorn. Platydoras armatulus has deeper scutes (depth of $10^{\text {th }}$ scute $12.0-16.6 \%$ of SL, $\mathrm{n}=59$ ), and midlateral scutes on caudal peduncle usually contacting, and often interdigitating with, middorsal and midventral caudal-peduncle plates. Platydoras hancockii has deeper scutes (depth of $10^{\text {th }}$ scute $12.0-17.8 \%$ of SL, $\mathrm{n}=37$ ), and pale yellow to white midlateral stripe usually punctuated with small dark spots in axils of few to many midlateral thorns.

Description. Morphometric data presented for 15 specimens (111.2-190.0 mm SL) in Table 2. Head moderately depressed, body more evenly rounded anteriorly, gradually becoming slightly compressed beyond dorsal fin origin to caudal peduncle; ventral surface moderately flattened from mouth to vent (Fig. 3). Dorsal profile gradually ascending and very gently rounded, convex to nearly straight, oblique from between anterior nares to middle pitline of supraoccipital, then straight and slightly less oblique from middle pitline to dorsal-fin origin; from dorsal-fin origin to caudal peduncle more gradually descending, very gently rounded, convex to nearly straight, oblique. Ventral profile gently rounded, convex to nearly straight from mouth to anal-fin origin; then rounded, convex, ascending more steeply along anal fin insertion to caudal peduncle. Caudal peduncle moderately long and relatively narrow (minimum depth $7.5-8.4 \% \mathrm{SL}$ ), profile gently concave dorsally and ventrally. Nuchal region subtriangular in cross-section; body depth greatest at dorsal-fin origin (19.3$26.6 \%$ of SL). Body width greatest across cleithral bulges (width 28.1-32.1\% of SL), tapering gradually to caudal fin.

Head moderately long (26.4-29.0\% SL, 66.4-73.8\% predorsal distance); in dorsal view weakly triangular with moderately short, rounded snout. Eyes subcircular, relatively small, without well-developed adipose eyelid (horizontal adipose eyelid diameter $10.3-13.4 \%$ predorsal distance), and placed dorsolaterally on head with center slightly less than one-third distance from snout tip to dorsal-fin origin. Bony orbits well separated (interorbital width $20.5-24.5 \%$ of predorsal distance); dorsal margin distinctly concave in dorsal view with arch not elevated above dorsal profile of head; enclosed largely by frontal dorsally with anteriormost quarter bordered by lateral ethmoid and posteriormost corner usually formed by anteriormost lateral corner of sphenotic or rarely by posterior lateral corner of frontal. Four infraorbitals (including lacrimal as infraorbital one), well ossified, superficially exposed; second one smallest, excluded from orbit; third one large, horizontal, forming ventral rim of orbit; fourth one narrower, vertical, completing posterior rim of orbit. Anterior and posterior nares well separated (internares distance 9.8$12.1 \%$ of predorsal distance). Anterior naris near anterior margin of snout, opening surrounded by distinct tube of skin. Posterior naris closer to eye than to anterior one, opening surrounded by tube of skin with anterior wall enlarged to form flap. Anterior cranial fontanel with elongate teardrop to wedge shape (tapered anteriorly); rounded posterior rim extending slightly beyond transverse line through centers of orbital concavities; opening enclosed by mesethmoid anteriorly and frontals posteriorly and laterally. Posterior cranial fontanel absent.

Mouth subterminal with moderately fleshy lips weakly expanded posteriorly as rounded flaps at corners of mouth. Lip surfaces rugose, weakly scalloped with low, rounded, closely-space papillae (particularly on lower lip). One pair of simple (non-fimbriate), slender maxillary barbels with tips extending well beyond pectoral-spine insertion, usually to near midlength (before tip) of postcleithral process; weakly compressed anteriorly; surfaces relatively smooth, studded with small papillae. Two pairs of simple, slender mandibular barbels; origin of inner pair slightly more anterior than outer pair, both origins near lower lip; outer pair longer with tips finishing near transverse line through anteriormost origin of pectoral-fin spines; inner pair usually finishing just shy of transverse line through ventralmost extent of gill openings; both pairs of barbels studded with small papillae. Branchiostegal membranes broadly united to isthmus.

Both jaws with many small, conical teeth confined to premaxillae and dentaries. Upper jaw teeth in single rectangular patch relatively continuous across premaxillae; teeth gradually decreasing in size from outermost to innermost rows. Lower jaw teeth in two subrectangular patches; each patch tapered laterally and weakly separated by narrow hiatus at symphysis; teeth relatively uniform in size. Outermost gill arch with 3 upper and 8-10 lower rakers $(n=4)$; rakers stiffened, moderately spaced and moderately long (length up to about 4 times width).

Nuchal shield well developed, moderately arched in transverse plane; medial furrow generally absent, sometimes evident but shallow from middle pitline of supraoccipital to suture between anterior and middle nuchal plates. Nuchal foramina absent. Anterior nuchal plate moderately wide (length about equal to width), pentagonal with posteriorly directed apex sutured to middle nuchal plate; also sharing transverse anterior suture with supraoccipital and lateral sutures with epioccipitals. Middle nuchal plate broad with shallowly concave lateral margins; anterior lateral tips of anterior wings sharing short, weak suture with posttemporal-supracleithrum (excluding epioccipital from bony margin of shield enclosing tympanal region). Posterior nuchal plate with paired limbs, each L- to widely V-shaped superficially with anterolaterally directed wing contacting third tympanal scute and posteriorly directed wing contacting infranuchal and first postinfranuchal scutes. Dorsal surfaces of nuchal shield and 


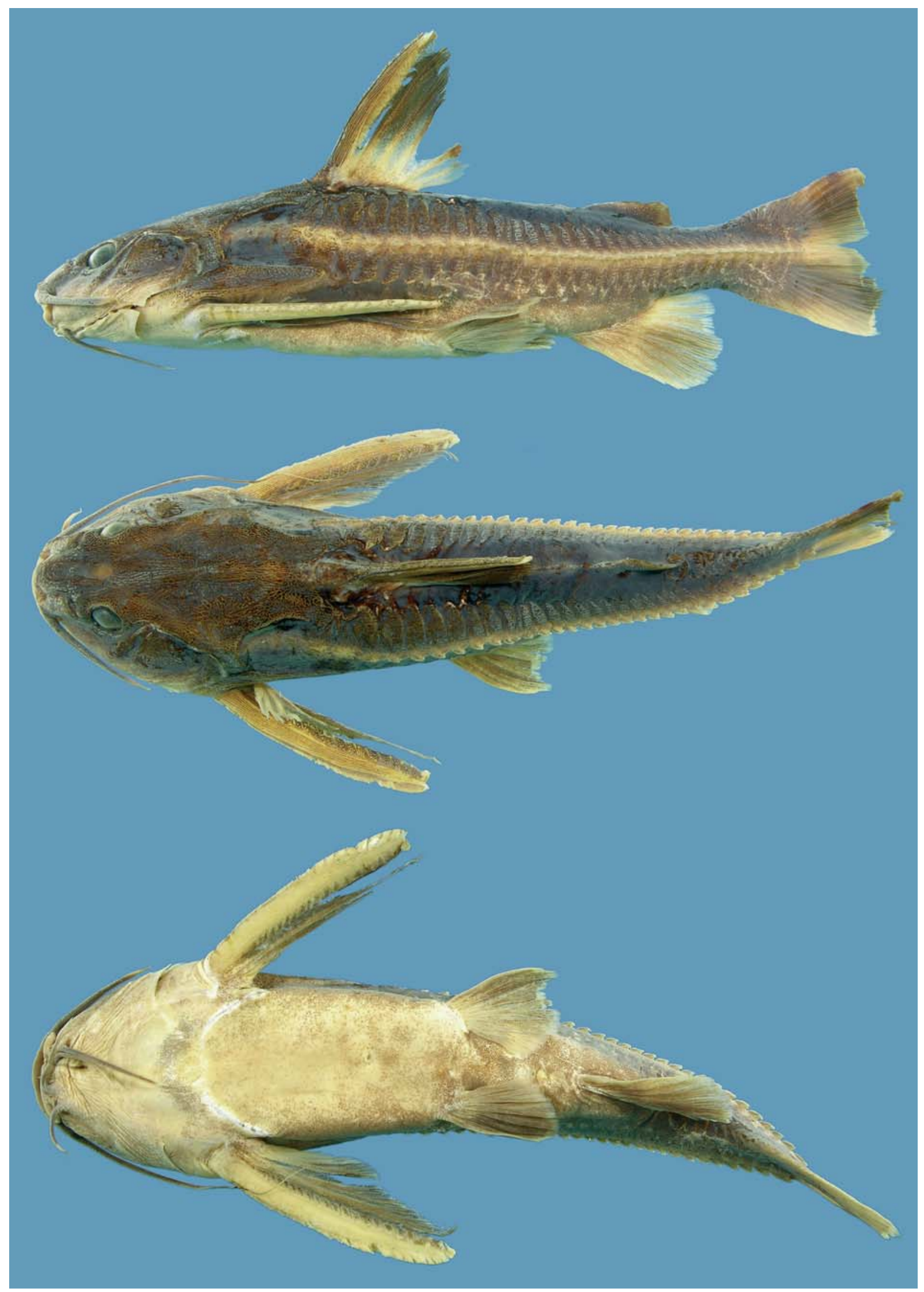

Fig. 3. Holotype of Platydoras brachylecis, MZUSP 43593, 137.7 mm SL, Brazil: Maranhão: lago dos Viana, Pindaré-Mearim river system, $03^{\circ} 13^{\prime}$ S $45^{\circ} 10^{\prime}$ W, B. V. O. Moura, April 1984. Photos by M. Arce H. 
neurocranial bones moderately rugose, ornamented with complex network of low fine ridges and granulations.

Pectoral girdle covered with skin ventrally. Postcleithral process long and narrow, lanceolate with acute tip; dorsal margin rises obliquely from base to moderately defined apex just distal to posterior margin of posttemporal-supracleithrum, then descends gradually, more or less linearly to posterior tip; ventral margin more or less straight, shallowly oblique; both margins largely entire or with minute dentitions. Postcleithral process with surface ornamentation separable into two longitudinal fields from base to posterior tip; dorsal field much wider, dominated by fine granulations and short irregular ridges; ventral field narrow, slightly elevated with more elongate longitudinal ridges and often separated posteriorly from dorsal field by low thin carina that continues to and often ventrally defines posteriormost tip of process.

Tympanal region with three separate ossifications (tympanal scutes); anterior two relatively small, weakly exposed, without well-defined dorsal and ventral wings; third tympanal scute large, well exposed with distinct dorsal and ventral wings spanning distance between posterior nuchal plate and postcleithral process, largely resembling subsequent midlateral scutes except with low medial carina instead of distinct thorn.

Sum of midlateral scutes including infranuchal: 56 (1), 57 (2), 58 (3), 59 (3 including holotype), or 60 (8). Midlateral scutes per left and right sides in 17 specimens: 28 (4), 29 (11), or 30 (19). Each midlateral scute with well-developed dorsal and ventral wings above and below sturdy thorn curved posteriorly (thorn sometimes indistinct on infranuchal scute, replaced by carina). Dorsal and ventral wings further separated by deep V-shaped notch along posterior margin in axil of thorn (location of lateral-line pores). Wings tall, subrectangular, subequal anteriorly (dorsal wing about a third taller) becoming equal near anal-fin origin; surfaces weakly ornamented with low, fine, longitudinal, roughly parallel ridges in vertical column along posterior half of scute; posterior margins nearly entire or with minute dentations imparted by ridges. Infranuchal scute contacts posterior nuchal plate dorsally, and ventrally slips beneath postcleithral process (but does not appear to contact internal surface of process). Scutes weakly overlapping (anterior margin embedded in skin), deepest anteriorly, becoming gradually shallower posteriorly; last scute usually on base of caudal fin beyond hypural flexure. Midlateral scutes on caudal peduncle not contacting middorsal and midventral caudal-peduncle plates (modified procurrent fin rays), distinctly separated from same plates by thin strip of skin.

Dorsal fin II,6 (includes spinelet); pectoral fin I,7 (very rarely I,8); pelvic fin i,6; anal fin iii-iv,8-9; caudal fin i, 7/8, i with 10-14 dorsal and ventral procurrent elements (rays and plates). Dorsal fin triangular with relatively short base. Dorsal-fin spine sturdy, gently curved posteriorly over entire length, laterally compressed and relatively smooth sided except for long, fine, nearly parallel striations running the length of the spine from base to tip; anterior margin (except distal-most tip) with 16-29 antrorse serrations; posterior margin (except basal third and distal-most tip) with 5-14 straight to weakly antrorse serrations. Serrations surrounded by thick, porous skin, obscuring their presence; anterior serrations small and crowded basally, becoming gradually larger and more spaced distally; penultimate usually largest; posterior dorsal-spine serrations weaker (thinner), more spaced; largest near midlength. Pectoral fin triangular with folded spine extending more or less to vertical through pelvic-fin origin. Pectoral-fin spines sturdy, gently curved, dorsoventrally compressed, and with surface striations similar to those on dorsal-fin spine; anterior (leading) margin with 26-37 antrorse serrations to tip; posterior (trailing) margin with 18-27 retrorse serrations to tip. Serrations similarly surrounded by thick, extremely porous skin; anterior and posterior serrations similarly developed (smaller and more crowded basally, largest subterminal), except posterior serrations slightly larger, more broadly triangular. Pelvic fins relatively short with broadly rounded distal margin when extended. Anal fin also with broadly rounded distal margin, middle rays longest (length more or less equal to anal-fin base). Caudal fin distinctly forked with moderately pointed lobes; lower lobe slightly broader and more rounded than upper. Upper and lower procurrent caudal-fin rays grading into series of three to five flat, laterally expanded and weakly overlapping plates. Procurrent plates extend to or near bases of adipose and anal fins, thereby framing caudal peduncle dorsally and ventrally. Adipose fin prominent, main portion elongate and tear-drop shaped (tapered anteriorly) with origin vertically aligned to that of the anal fin. Adipose fin continues anteriorly as a low, narrow, fleshy ridge that begins approximately at the midpoint between verticals through last dorsal-fin ray and anal-fin origin.

Gas bladder two part with anterior (main) bladder and much smaller posterior (terminal) bladder (Fig. 4); bladder walls moderately thick and smooth. Main bladder cordiform with internal T-shaped septum that partially isolates single anterior chamber and completely divides paired posterior chambers. Posterior bladder elliptical, without internal septum. Lumen enclosed by terminal bladder apparently continuous with that of only one of the two posterior chambers of main bladder through a narrow opening at point of constriction between two bladders.

Coloration. Ground color of dorsal and lateral surfaces of head and body dusky, dark gray-brown; undersurfaces largely pale white to yellow. Midlateral sides with distinct light stripe along central portions of scutes and thorns (small dark spots in axils of thorns absent); stripe continues anteriorly through tympanal region, becoming less distinct as it converges dorsally with its pair in interorbital region. Thin faint light middorsal stripe usually evident from dorsal to adipose fin and sometimes evident in posterior nuchal region. Barbels dusky gray-brown with mandibular barbels somewhat lighter than maxillary barbels. Dorsal fin with dusky gray-brown spine 
and dusky spot in distal half of anterior three to four rays and intervening membranes; remaining portions relatively pale with few scattered pigment. Adipose fin largely dusky graybrown, becoming somewhat lighter towards distal margin. Pectoral fin with light to dusky spine; anterior three rays and intervening membranes usually darker, gray-brown; remaining portions relatively pale. Pelvic fins with anterior three to four rays and intervening membranes dusky, becoming lighter, pale posteriorly. Anal fin with large dusky blotch on central rays and membranes, relatively lighter, pale anteriorly and posteriorly. Caudal fin with wide dark gray-brown streaks on central portions of upper and lower lobes (streaks continuous with gray-brown ground color on sides); remaining portions relatively pale.

Distribution. Platydoras brachylecis is known from basins of rio Mearim, rio Pindaré, rio Itapecuru and rio Parnaíba, northeastern Brazil (Fig. 5). Fowler (1941:139) reported three specimens (ANSP 81733) from "Fortaleza, Ceará [State]", Brazil, collected by Rodolpho von Ihering in 1937. There are no major rivers emptying into the Atlantic Ocean at the coastal city of Fortaleza, and Ihering's specimens, with bellies slit from pectoral girdle to vent, may have been obtained from a local market. Their precise origin remains uncertain.

Ecological notes. Menezes \& Menezes (1948) studied diet and relative gut length among 26 specimens (78-129 mm SL) from lagoa de Nazaré, Floriano municipality, Piauí State, Brazil. Gut contents were dominated by larva and adult insects (found in 17 specimens) with lesser amounts of fishes, shrimp and other crustaceans, plant remains and small stones.

Etymology. The specific name brachylecis is derived from the Greek brachy (short), and lekis (plate or dish), in reference to the relatively shallow midlateral scutes.

Remarks. Species commonly known as "graviola" in the Parnaíba River, "grangiola" in the Itapecuru River, and "corró" in the Mearim river.

\section{Discussion}

Platydoras costatus has long been misunderstood despite the early illustrations of Gronow's type specimen (P1. 5, figs. 1 and 2 in Gronovius, 1756) upon which Linnaeus (1758) based this name. Gronow's (Gronovius, 1756) illustration depicts a Platydoras with dorsal head and midlateral scutes uniformly colored. Platydoras costatus, however, is often applied to specimens with a distinct, continuous light midlateral stripe (white to yellow in life) that converges dorsoanteriorly with its pair in the interorbital region. Based on our examination of Platydoras from throughout its wide range, only specimens from coastal drainages of Suriname and French Guiana (i.e., Corantijn, Suriname, Maroni) lack a distinct light stripe on the head and sides, evidence that the types of $P$. costatus originated from this region.

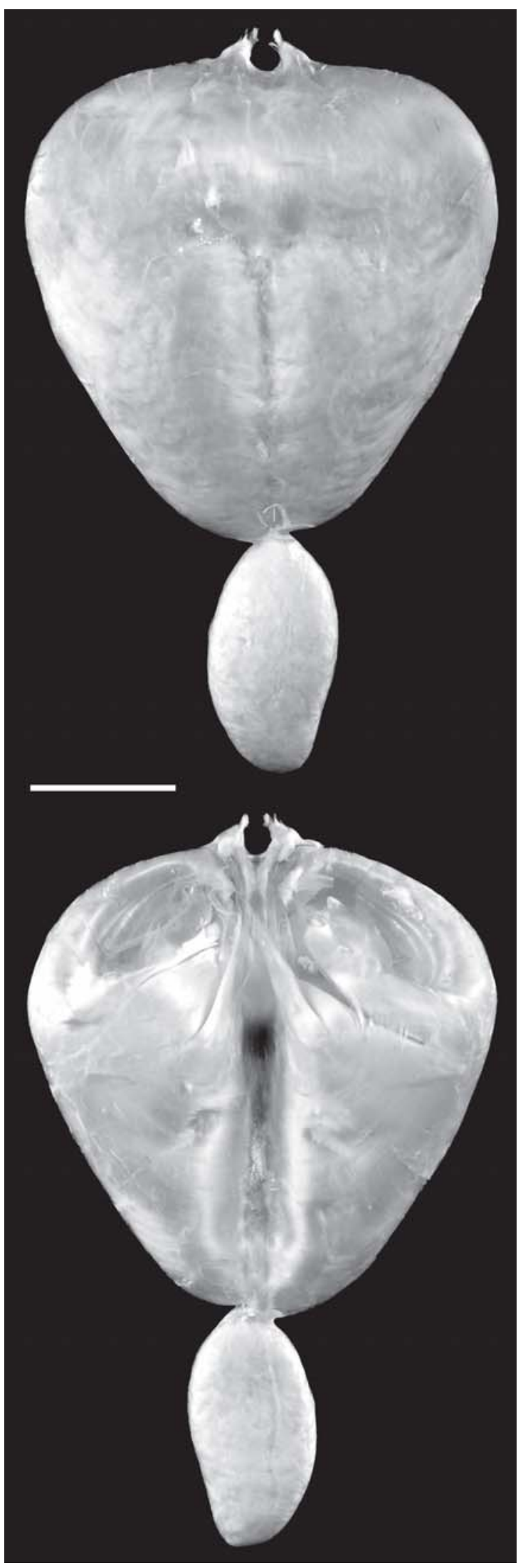

Fig. 4. Ventral (top) and dorsal (bottom) views of gas bladder in Platydoras brachylecis, ANSP 187051, 179 mm SL. Scale bar $=1 \mathrm{~cm}$. Photos by M. Sabaj Pérez. 
Table 2. Morphometrics of Platydoras brachylecis, new species, reported for holotype, MZUSP 43593, and all measured specimens $(\mathrm{n}=15$ total $)$.

\begin{tabular}{|c|c|c|c|c|}
\hline & holotype & $\begin{array}{c}\text { range } \\
(\mathrm{n}=15)\end{array}$ & mean & SD \\
\hline Standard Length (SL) & 137.7 & $111.2-190.0$ & 146.9 & 25.92 \\
\hline \multicolumn{5}{|c|}{ Percents of standard length } \\
\hline Head L (HL) & 29.0 & $26.4-29.0$ & 28.0 & 0.71 \\
\hline Predorsal D (PdD) & 39.4 & $38.7-42.8$ & 40.3 & 1.07 \\
\hline Snout-postcleithral process D (SPcPD) & 43.9 & $43.6-48.1$ & 45.2 & 1.32 \\
\hline Dorsal origin-post. adipose D (DOAD) & 46.5 & $45.4-50.7$ & 48.1 & 1.52 \\
\hline Adipose-caudal D (AdCD) & 17.9 & $14.2-17.9$ & 15.7 & 1.05 \\
\hline Prepectoral D (PpD) & 24.0 & $22.9-25.1$ & 23.9 & 0.62 \\
\hline Pectoral-pelvic D (PPD) & 31.0 & $31.0-37.4$ & 34.6 & 1.61 \\
\hline Pelvic-anal D (PAD) & 19.7 & $16.2-21.5$ & 18.9 & 1.40 \\
\hline Anal-caudal D (AnCD) & 18.7 & $15.0-18.7$ & 17.1 & 1.09 \\
\hline Dorsal spine L (DSL) & 26.8 & $23.9-33.1$ & 27.7 & 3.16 \\
\hline Pectoral spine L (PSL) & 34.7 & $33.7-43.0$ & 37.1 & 2.90 \\
\hline Pelvic fin L (PFL) & 16.6 & $13.1-16.9$ & 15.3 & 1.14 \\
\hline Anal fin Base (AnFB) & 13.3 & $10.1-13.9$ & 12.4 & 0.99 \\
\hline Head Width (HW) & 23.9 & $21.6-25.1$ & 23.8 & 1.02 \\
\hline Cleithral Width (CW) & 28.5 & $28.1-32.1$ & 29.9 & 1.13 \\
\hline Head Depth at middle pitline (HD) & 18.2 & $16.8-20.6$ & 19.4 & 1.05 \\
\hline Body Depth (BD) & 20.8 & $19.3-26.6$ & 22.5 & 1.90 \\
\hline Caudal peduncle Depth (CPD) & 8.1 & 7.5-8.4 & 7.9 & 0.27 \\
\hline $5^{\text {th }}$ scute Depth (SD5) & 11.9 & $11.0-14.1$ & 12.6 & 1.03 \\
\hline $10^{\text {th }}$ scute Depth $(\mathrm{SD} 10)$ & 9.9 & $8.8-11.9$ & 10.4 & 1.03 \\
\hline \multicolumn{5}{|c|}{ Percents of predorsal distance } \\
\hline Head L (HL) & 73.8 & $66.4-73.8$ & 69.4 & 2.08 \\
\hline Adipose eyelid Diameter (AED) & 12.1 & $10.3-13.4$ & 11.9 & 0.89 \\
\hline Orbital diameter (OD) & 13.5 & $11.4-15.0$ & 13.8 & 1.12 \\
\hline Snout-anterior nares D (SAND) & 7.9 & $5.3-8.2$ & 6.9 & 0.90 \\
\hline Snout-posterior nares D (SPND) & 19.3 & $15.3-19.3$ & 17.3 & 1.22 \\
\hline Snout-posterior orbit D (SPOD) & 39.5 & $37.4-41.3$ & 39.1 & 1.00 \\
\hline Ant. nares-post. orbit D (ANPOD) & 33.2 & 30.4-34.7 & 32.7 & 1.13 \\
\hline Post. nares-post. orbit D (PNPOD) & 20.1 & $19.9-23.6$ & 21.6 & 1.07 \\
\hline Internares D (ID) & 11.6 & $9.8-12.1$ & 10.8 & 0.76 \\
\hline Postorbital L (PL) & 65.5 & $65.2-67.8$ & 66.5 & 0.91 \\
\hline Postcleithral process L (PcPL) & 41.2 & $41.2-51.8$ & 45.4 & 3.00 \\
\hline Postcleithral process Depth (PcPD) & 10.6 & $8.6-12.3$ & 10.3 & 0.95 \\
\hline Interorbital Width (IW) & 22.9 & $20.5-24.5$ & 22.9 & 1.39 \\
\hline Head Width (HW) & 60.8 & $53.3-62.6$ & 59.0 & 2.23 \\
\hline Cleithral Width (CW) & 72.4 & $67.9-78.7$ & 74.3 & 3.47 \\
\hline Head Depth at middle pitline (HD) & 46.2 & $41.4-52.6$ & 48.2 & 2.74 \\
\hline Body Depth (BD) & 53.0 & $47.6-66.8$ & 55.8 & 4.43 \\
\hline \multicolumn{5}{|c|}{ Percents of postcleithral process length } \\
\hline Postcleithral process Depth & 25.9 & $18.1-29.4$ & 22.9 & 3.11 \\
\hline \multicolumn{5}{|c|}{ Percents of body depth at $5^{\text {th }}$ Scute } \\
\hline $5^{\text {th }}$ scute Depth (SD5) & 62.6 & $52.8-86.6$ & 68.3 & 8.72 \\
\hline \multicolumn{5}{|c|}{ Percents of body depth at $10^{\text {th }}$ Scute } \\
\hline $10^{\text {th }}$ scute Depth (SD10) & 57.1 & $51.4-67.5$ & 59.7 & 6.13 \\
\hline
\end{tabular}

The distinctiveness and width of the light stripe on the head and sides vary both ontogenetically and geographically in other Platydoras (i.e., P. armatulus, P. hancockii and $P$. brachylecis), and the taxonomic utility of this character remains unclear for these species. Another variable pigmentation feature is the occurrence of small black spots in the axils of the medial thorns of the midlateral scutes. In P. costatus these black spots are usually evident in the axils of all medial thorns (though sometimes poorly contrasted with the dark plates), and Kner (1855) noted their occurrence in his de- scription of $D$. dentatus (tentatively a junior synonym of $P$. costatus). In $P$. hancockii the black spots are usually present and more distinct against the light midlateral stripe (particularly in juveniles), but may not occur in the axils of all thorns. Dark axillary spots are always absent in $P$. armatulus and $P$. brachylecis.

Pigmentation aside, Platydoras from throughout its distribution exhibits variation in the shape of the head and postcleithral process, relative eye size, scute depth, and the number of midlateral scutes. All of this variation (coloration, morphometric and meristic), however, is subtle, complex and usually characterized by overlapping ranges among the four valid species recognized herein: $P$. armatulus, $P$. brachylecis, $P$. costatus, and P. hancockii. For instance, P. hancockii exhibits the largest eye size (horizontal diameter 56.1-88.9\% of interorbital width, $\mathrm{n}=37,86.4-235.0 \mathrm{~mm} \mathrm{SL}$ ) but overlaps with ranges for $P$. armatulus $(41.2-58.0 \%, \mathrm{n}=33,99.0-216.0$ $\mathrm{mm}$ SL, Amazonas and Paraguay-Paraná basins; and 47.0$65.1 \%, \mathrm{n}=26,81.4-169.0 \mathrm{~mm} \mathrm{SL}$, Orinoco basin), P. brachylecis $(42.9-60.4 \%, \mathrm{n}=15,111.2-190.0 \mathrm{~mm} \mathrm{SL})$ and $P$. costatus (38.5$62.8 \%, \mathrm{n}=8,73.1-271.0 \mathrm{~mm} \mathrm{SL})$. Specimens from the Xingu, Tocantins and Tapajós appear separable into two groups based on eye size. Specimens with large eyes (horizontal diameter $73.0-86.2 \%$ of interorbital width, $\mathrm{n}=5,102.2-154.0 \mathrm{~mm}$ SL) exhibit a size range within that of $P$. hancockii, whereas specimens with small eyes (horizontal diameter 47.5-62.1\%, $\mathrm{n}$ $=5,114.3-175.5 \mathrm{~mm} \mathrm{SL}$ ) fall within the ranges of $P$. armatulus

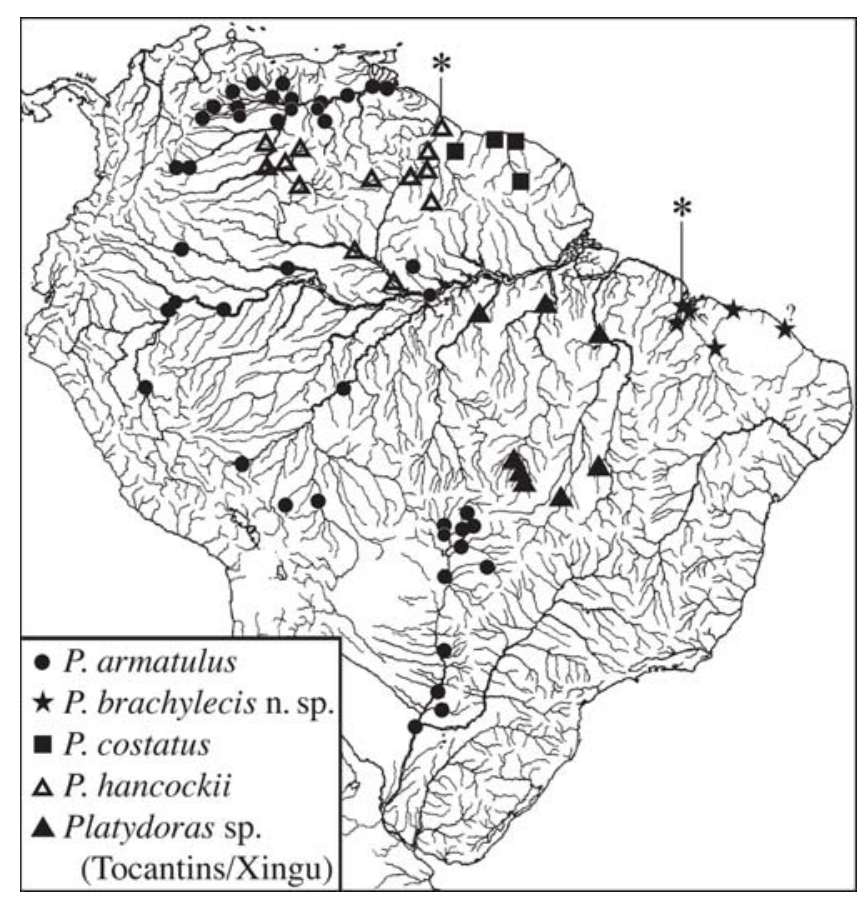

Fig. 5. Distribution of specimens of Platydoras examined. Type localities denoted with asterisk except for Platydoras armatulus (= Brazil, Paraná, not below $27^{\circ} 30^{\prime} \mathrm{S}$ ) and $P$. costatus (= likely Suriname). ?= locality data questionable. Base map by M. Weitzman. 
and $P$. costatus. Despite correspondences in eye size assignment of these specimens to any of the valid species recognized here remains premature. They are grouped together as Platydoras sp. and additional investigation is needed to sort out the correct placement of these specimens among nominal or additional new species.

\section{Key to species of Platydoras.}

1. Sides without light midlateral stripe; midlateral scutes very shallow, depth of $10^{\text {th }}$ scute $7.2-9.8 \%$ of SL; coastal drainages of Suriname and French Guiana...Platydoras costatus

1'. Sides with light midlateral stripe; midlateral scutes shallow to deep, depth of $10^{\text {th }}$ scute $8.8-17.8 \%$ of SL ...............

2. Light midlateral stripe usually punctated with small dark spots in axils of few (anteriorly) to all midlateral thorns (except in some specimens from Negro drainage); eye relatively large, horizontal diameter of adipose eyelid usually $>59 \%$ (range $56.1-88.9 \%$ ) of interorbital width; upper Orinoco, Negro, Essequibo and Demerara drainages......... ..Platydoras hancockii

2'. Light midlateral stripe solid, without dark spots; eye relatively small, horizontal diameter of adipose eyelid usually $<59 \%$ (range $41.2-65.1 \%$ ) of interorbital width.............. 3

3. Midlateral scutes shallow, depth of $10^{\text {th }}$ plate $8.8-11.9 \%$ of SL; midlateral scutes on caudal peduncle clearly separated by thin strip of skin from middorsal and midventral caudalpeduncle plates (i.e., modified procurrent caudal-fin rays); coastal drainages from Pindaré to Parnaíba rivers, northeastern Brazil........................ Platydoras brachylecis

$3^{\prime}$. Midlateral scutes deep, depth of $10^{\text {th }}$ plate $12.0-16.6 \%$ of $\mathrm{SL}$; midlateral scutes on caudal peduncle usually contacting, and often interdigitating with, middorsal and midventral plates (except some specimens from lower Amazon); lower Orinoco, Amazon and Paraguay-Paraná basins...... .Platydoras armatulus

Material examined. Platydoras armatulus.-Argentina: ANSP 181008,1 , purchased from aquarium shop in Corrientes, presumably from vicinity. Bolivia: Beni: CBF 0179, 5, río Machupo; MNHN 1988-1023, 3, río Mamoré, Is. Santa Rosa, Trinidad; USNM 305825, 1, río Curiraba (Mamoré Dr.), E.B.B Campamento Trapiche. Brazil: MNHN 4152, holotype of Doras armatulus Valenciennes in Cuvier \& Valenciennes 1840, rio Paraná, not below 27³0'S latitude; Amazonas: INPA 4818, 24, rio Uatumã, barragem de Balbina (dam), Presidente Figueiredo Municipality; INPA 4940, 3, rio Japurá, Paraná Jaraua, Japurá Municipality; MCP 33193, 5, lago Jaraqui (system of lago Jarauá), Alvarães, 0244'10"S 6504’37"W; USNM 320038, 1, rio Amazonas at Albano, east of Itacoatiara; Mato Grosso: ANSP 53872, 1, Descalvados, $16^{\circ} 45^{\prime}$ 'S 57² $42^{\prime} \mathrm{W}$; CBF 2107, 1 , rio Cuiabá; MCP 15538, 1, rio Paraguai, Caceres; MCP 29043, 1, and MCP 29049, 1, bacia do rio Bento Gomes (Paraguai Dr.), Poconé, $16^{\circ} 15^{\prime} \mathrm{S} 56^{\circ} 37^{\prime} \mathrm{W}$; MCP 36416 , 1 , rio Guaporé, Pontes and Lacerda, $15^{\circ} 12^{\prime} 58^{\prime \prime S} 59^{\circ} 21^{\prime} 18^{\prime \prime W}$; MZUSP 4424, 1, rio Cuiabá, Santo Antônio do Leverger Municipality, $15^{\circ} 52^{\prime} \mathrm{S} 56^{\circ} 05^{\prime} \mathrm{W}, 1965$; MZUSP 27711, 1, rio Taquari, Coxim Municipality, $18^{\circ} 30^{\prime} \mathrm{S}$ 544ㄴ'W; MZUSP 38776, 1, rio Cuiabá, Bocaiuval, Barão de Melgaço Municipality, $16^{\circ} 11^{\prime} \mathrm{S}, 5^{\circ} 57^{\prime} \mathrm{W}$; MZUSP 62663, 1, rio
Cuiabá, Porto de Barão de Melgaço, Barão de Melgaço Municipality; MZUSP 62665, 2, rio Cuiabá, Sangradouro Grande, Barão de Melgaço Municipality; MZUSP 62666, 2, rio Cuiabá, Barão de Melgaço Municipality, $16^{\circ} 11^{\prime} \mathrm{S} 5^{\circ} 57^{\prime} \mathrm{W}$; USNM 326422, 1 , rio Paraguay at Caceres and its environs; Mato Grosso do Sul: MZUSP 36350 , 1, rio Paraguai basin, Ladário, Corumbá Municipality, $19^{\circ} 00^{\prime} \mathrm{S} 57^{\circ} 39^{\prime} \mathrm{W}$; MZUSP 52532, 3, rio Piquiri, hidden bay, pantanal de Paiaguás, Santo Antônio farm, $17^{\circ} 18^{\prime} \mathrm{S} 56^{\circ} 43^{\prime} \mathrm{W}$; Rondônia: MZUSP 28379, 3, rio Madeira, lago Piauí, Foz do rio Jamari, 08²7'S 6330'W. Colombia: Amazonas: IAvH-P 491, 1, río Amazonas; IAvH-P 6051, 1, quebrada Mata-mata, Leticia; Arauca: IAvH-P 2760, 5, río Aguas Limón, Arauquita; IAvH-P 4822, 3, Río Aguas-Limón, Arauquita, 3 Nov 1993; IAvH-P 6052, 2, caño Jesus; IAvH-P 8107, 5, caño Agua Limón, bridge on Arauca-Tame road, km 60, La Becerra; Caquetá: IAvH-P 859, 1, quebrada Aduche; IAvH-P 6050, 1, quebrada El Penal, Araracuara; IAvH-P 6053, 1, río Caquetá, Araracuara; Meta: ANSP 133134, 13, and ANSP 134457, 229, tributary of caño La Raya (Meta Dr.), $1 \mathrm{~km} \mathrm{~N}$ of La Siberia, $04^{\circ} 05^{\prime} \mathrm{N} 73^{\circ} 05^{\prime} \mathrm{W}$; ANSP 134836,24 , tributary of caño El Chocho (Meta Dr.), ca. $5 \mathrm{~km} \mathrm{~N}$ of La Siberia, $04^{\circ} 07^{\prime} \mathrm{N} 73^{\circ} 05^{\prime} \mathrm{W}$; ANSP 136486, 3, and ANSP 150676, 9, quebrada Venturosa (trib Meta), between La Balsa and Puerto Lopez, $04^{\circ} 05^{\prime} \mathrm{N} 72^{\circ} 58^{\prime} \mathrm{W}$; IAvH-P 1037, 1, and IAvH-P 1038, 1, laguna San José, río Manacacias, Puerto Gaitán; IAvH-P 1467, 2, laguna Las Maracas, río Manacacias, Puerto Gaitán; IAvH-P 4887, 11, Río Manacacias; MCP 15357, 5, same data as ANSP 134836. Paraguay: USNM 181694, 1, lago Ypacaray near San Bernardino; Central: UMMZ 207420, 1, W shore of lago Ypacarai (Paraguay Dr.) at lakeside park in Aregua, rio Salado, $25^{\circ} 18^{\prime} 48^{\prime \prime} \mathrm{S} 57^{\circ} 20^{\prime} 42^{\prime \prime} \mathrm{W}$; Concepcion: UMMZ 207839, 3, río Aquidaban (Paraguay Dr.), at Paso Horqueta, ca. 24 km NW of Loreto, 2303' $48^{\prime \prime S} 27^{\circ} 23^{\prime} 24^{\prime \prime} W$; Paraguari: UMMZ 207534, 3, small bay along río Tabicuary (Paraguay Dr.) at km 159 and just $\mathrm{N}$ of new bridge on route \#1 at Villa Florida, $26^{\circ} 24^{\prime} 00^{\prime \prime} \mathrm{S}$ 5704'48"W. Peru: Loreto: ANSP 181047, 2, purchased from ornamental fishermen in Belen, Iquitos; reportedly from río Itaya \& associated lagoons (Amazon Dr.); INHS 43287, 2, río Itaya \& Quebrada Mazana (Amazonas Dr.), Itaya site $11 \mathrm{~km} \mathrm{SSW} \mathrm{of} \mathrm{Iquitos,}$ Mazana site at its confluence with Itaya just $\mathrm{S}$ of Iquitos, 034' 47.6"S 73¹8'02.9"W; INHS 43332, 1, río Itaya (Amazonas Dr.), $11 \mathrm{~km} \mathrm{SSW}$ center of Iquitos, bearing $39^{\circ}, 03^{\circ} 49^{\prime} 47.6^{\prime \prime S}$ $73^{\circ} 18^{\prime} 02.9^{\prime \prime} \mathrm{W}$; INHS 53948, 1, río Itaya (Amazonas Dr.), approx. 10-15 km SSW center of Iquitos; MUSM 3490, 1, cocha Aguajal, Caserio Luceropata; USNM 86282, 1, río Morona; USNM 284629 , 1, río Itaya, main river channel and lower portions of caños, 5-20 $\mathrm{km}$ upstream from Belem (Iquitos), $03^{\circ} 51^{\prime} \mathrm{S} 73^{\circ} 12^{\prime} \mathrm{W}$; USNM 284630, 1, río Manite system, caño entering Manite about $10 \mathrm{~km}$ upriver jet. Manite and Amazonas, 0332'S 72॰40'W; USNM 284631, 1, quebrada Corrientillo, at Corrientillo, on rd. running W from Iquitos to río Nanay, $03^{\circ} 50^{\prime} \mathrm{S} 73^{\circ} 13^{\prime} \mathrm{W}$; USNM 284632, 1, green water caño on left bank of río Manite, ca. $8 \mathrm{~km}$ upriver of jet. Manite and Amazonas, 03 ${ }^{\circ} 1^{\prime}$ 'S $72^{\circ} 40^{\prime} \mathrm{W}$; USNM 284633, 14, Yarinacocha, side caño, District Coronel Portillo, $08^{\circ} 16^{\prime}$ 'S $74^{\circ} 36^{\prime} \mathrm{W}$; USNM 167841 [ex. 15875], 1, río Morona; Madre de Dios: MUSM 16190, 1, río Tambopata, lago Tres Chimbadas; Ucayali: ANSP 120336, 1, Yarinacocha, near Pucallpa, 08 $15^{\prime}$ 'S $74^{\circ} 43^{\prime} \mathrm{W}$; MUSM 0584, 1, río Ucayali, Pucallpa, Utuquimá; USNM 284628, 6, main channel and side pools of río Ucayali, ca. $10 \mathrm{~km}$ upstream of Pucalllpa, $08^{\circ} 31^{\prime}$ S $74^{\circ} 22^{\prime} \mathrm{W}$. Venezuela: Anzoategui: ANSP 166801, 1, río Orinoco Basin, Soledad, L. Tineo, 08¹1’25"N 6328'20"W; Apure: ANSP 179247, 2, río Claro (Orinoco Dr.), presumably in vicinity of San Fernando de Apure; INHS 28055, 1, 
río Arauca (Apure Dr.), overflow Pool, N edge of Elorza, $07^{\circ} 4.18^{\prime} \mathrm{N}$ 69²9.86 'W; INHS 28119, 1, caño Salina (Apure Dr.), $07^{\circ} 14.62^{\prime} \mathrm{N}$ 7049.40’W; INHS 28191, 2, caño Guaritico (= caño Maporal, Apure Dr.), 58 km SSW Bruzual, 07³3.21'N 69³8.70'W; INHS 29764, 2, caño Guaritico (Apure Dr.), 58 km SSW Bruzual, $07^{\circ} 33.21^{\prime} \mathrm{N} 6^{\circ} 38.69^{\prime} \mathrm{W}$; INHS 29822, 17, caño Caicara (Apure Dr.), 2 km N Lave, $07^{\circ} 33.95^{\prime} \mathrm{N} 69^{\circ} 15.48^{\prime} \mathrm{W}$; INHS 30042, 1, caño Caicara (Apure Dr.), N Laye on Hwy. 2, 07³3.59'N 69¹5.48'W; INHS 30056, 16, caño Guaritico (= caño Maporal, Apure Dr.), 58 km SSW Bruzual, 07³3'24"N 69³8'68"W; INHS 32062, 7, caño Guaritico (Apure Dr.), 58 km SSW Bruzual, 07³3'21"N 69³8'69"W; INHS 55357, 1, caño Potrerito (Orinoco Dr.), ca. 15 km N Puerto Paez, on rd. to San Fernando, 06²4'43"N 67³1'55"W; INHS 56185, 1, río Claro (Orinoco Dr.), 102 rd. km N Puerto Paez on rd. to San Fernando, 0709'08"N 67³8'06"W; INHS 61495, 2, caño San Miguel (Cinaruco-Orinoco Dr.), 06³4’24"N 67¹7’32"W; USNM 258128, 1, side channel of río Apure ca. $5 \mathrm{~km} \mathrm{~W}$ of San Fernando, $07^{\circ} 53^{\prime} \mathrm{N} 67^{\circ} 29^{\prime} \mathrm{W}$; USNM 258163, 5, side channel of río Apure about $3 \mathrm{~km} \mathrm{~W}$ of center of San Fernando, $07^{\circ} 53^{\prime} \mathrm{N}$ $67^{\circ} 29^{\prime} \mathrm{W}$; USNM 260221, 20, caño $1 \mathrm{~km}$ S of ferry crossing on río Apurito, where crossed by rd. from San Fernando to Cunaviche, 07³3'N 67³8'W; Barinas: INHS 35479, 1, caño Capa (MasparroApure Dr.), 2 mi E El Tombor, 08²1'35"N 6946’07"W; MCP 19914,2 , caño Indiecito, cerca de la boca in rio Suripa; Bolivar: ANSP 135593, 4, caño Chuapo, ca 20 min. downstream from Jabillal (opposite bank) on río Caura, $07^{\circ} 07^{\prime} \mathrm{N} 65^{\circ} 00^{\prime} \mathrm{W}$; ANSP 135603 , 22, caño Barranca, ca 1.25 hours downstream from Jabillal (opposite bank) on río Caura, $07^{\circ} 08^{\prime} \mathrm{N} 65^{\circ} 04^{\prime} \mathrm{W}$; ANSP 135617 , 75, caño Puerto Cabello at Puerto Cabello, $07^{\circ} 10^{\prime} \mathrm{N} 65^{\circ} 01^{\prime} \mathrm{W}$; ANSP 139568, 1 , isolated backwater of río Nichare, ca $10 \mathrm{~min}$. from río Nichare-río Caura junction, $06^{\circ} 35^{\prime} \mathrm{N} 64^{\circ} 48^{\prime} \mathrm{W}$; ANSP 139855, 6, small caño tributary of río Mato (left bank), $07^{\circ} 08^{\prime} \mathrm{N}, 65^{\circ} 10^{\prime} \mathrm{W}$; ANSP 160379 , 1 , confluence of río Orinoco and río Caura (las piedras), $07^{\circ} 38^{\prime} 36^{\prime \prime} \mathrm{N}$ 6450'W; INHS 55526, 1), río Chaviripa (Orinoco Dr.), on CaicaraPuerto Ayacucho Rd., 0707'57"N 66²9'56"W; Delta Amacuro: AMNH 217703, 1, and ANSP 149463, 1, caño Araguao, small side caño of río Orinoco, 112 nautical mi. upstream from sea bouy, $08^{\circ} 38^{\prime} \mathrm{N} 61^{\circ} 43^{\prime} \mathrm{W}$; ANSP 177995, 5, río Orinoco, first small cano on W side of caño Paloma, $100 \mathrm{~m}$ above mouth, 92 nautical mi. from sea bouy, $08^{\circ} 29^{\prime} \mathrm{N} 61^{\circ} 25^{\prime} \mathrm{W}$; ANSP 180890 , 18 , río Orinoco on north shore at Isla Portuguesa, ca. mi. 117, in caño Anabata, $08^{\circ} 37^{\prime} 20^{\prime \prime} \mathrm{N} 61^{\circ} 47^{\prime} 30^{\prime \prime} \mathrm{W}$; UMMZ 211344, 1, same data as AMNH 217703; USNM 222840, 1, río Orinoco, small caño at mouth of caño Fiscal, 64 nautical mi. upstream from sea buoy, $08^{\circ} 32^{\prime} \mathrm{N}$ $61^{\circ} 02^{\prime} \mathrm{W}$; USNM 222845, 1 , río Orinoco, small caño entering W end of caño Sacoroco, $08^{\circ} 35^{\prime} \mathrm{N} 61^{\circ} 42^{\prime} \mathrm{W}$; USNM 222846, 25, same data as AMNH 217703; Guarico: ANSP 150675, 16, río Portuguesa, Camaguan Swamp, on W side of highway to San Fernando de Apure, ca $2 \mathrm{~km} \mathrm{~N}$ of Camaguán, $08^{\circ} 14^{`} \mathrm{~N} 67^{\circ} 36^{\prime} \mathrm{W}$; ANSP 163475, 1, lagunas de 'Prestamos' between La Antena and caño Falcon; ANSP 163478, 1, río Portuguesa, caño Falcon (Laguna 'La Raya'), near Camaguán; INHS 33908, 1, trib. río San Bartolo (Orinoco Dr.), P.N. Aguaro-Guariquito, Morichal Carnestolendo, $12 \mathrm{~km} \mathrm{SE} \mathrm{La}$ Esperanza, 08²1' $11^{\prime \prime} \mathrm{N} 66^{\circ} 40 ’ 22 " \mathrm{~W}$; INHS 34294, 1, río Mocapra (Orinoco Dr.), P.N. Aguaro-Guariquito, La Esperanza, 08¹6’39"N 664'21"W; INHS 34351, 6, río Aguaro (Orinoco Dr.), P.N. AguaroGuariquito, $15 \mathrm{~km} \mathrm{~S}$ Paso Cachimbo, 0803'06"N 66²5’34"W; INHS 34498, 7, río San Bartolo (Orinoco Dr.), P.N. AguaroGuariquito, Aguas Muertas, 0804'14"N 66²4'50"W; INHS 34577 , 1, laguna Caricare (Guariquito-Orinoco Dr.), $\mathrm{N}$ of Medano de Gomez, 0750’41"N 66³2’10"W; INHS 34854, 3, río San Bartolo
(Orinoco Dr.), P.N. Aguaro-Guariquito, Aguas Muertas, $08^{\circ} 06^{\prime} 30^{\prime \prime} \mathrm{N}$ 6640'19"W; INHS 61867, 3, río San Bartolo (Guariquito-Orinoco Dr.), at mouth, near Aguas Muertes, P.N. Aguaro-Guariquito, $08^{\circ} 04^{\prime} 40^{\prime \prime N} 66^{\circ} 40^{\prime} 00^{\prime \prime W}$; UMMZ 214750, 1, caño Falcon (Portuguesa Dr.), near Camaguán, ca. $25 \mathrm{~km} N$ of San Fernando de Apure; USNM 257990, 1, río Orituco where crossed by rd. from Calabozo, $08^{\circ} 52^{\prime} \mathrm{N} 67^{\circ} 18^{\prime} \mathrm{W}$; Monagas: USNM 222842, 1 , río Orinoco, small caño near mouth of caño Guarguapo, 146 nautical mi. upstream from sea buoy, $08^{\circ} 41^{\prime} \mathrm{N} 62^{\circ} 14^{\prime} \mathrm{W}$; USNM 265655 , 2 , secondary caño about $500 \mathrm{~m}$ from its mouth in caño Guarguapo,

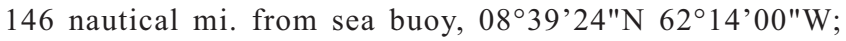
Portuguesa: INHS 31956, 1, caño Igues (Portuguesa Dr.), La Capilla.

Platydoras costatus.-Suriname: BMNH 1866.8.19.1-3, 1, 271 mm SL, syntype of Doras helicophilus Günther 1868, Maroni River; NMW 46615, 2, Paramaribo; NMW 46616, 1; NMW 46617, 1, Suriname River at Berg en dal; NMW 46869, 112.4 mm SL, holotype of Doras dentatus Kner 1855; UF 16269, 1, $125.1 \mathrm{~mm}$ SL, Marowijne River at Albina; USNM 226186, 2, Matappi Creek, Corantijn basin, $05^{\circ} 01^{\prime} \mathrm{N} 57^{\circ} 17^{\prime} 30^{\prime \prime} \mathrm{W}$.

Platydoras hancockii.-Brazil: Amazonas: INPA 4939, 3, rio Caures, lago Carurarra, Barcelos Municipality; INPA 4947, 1, rio Negro, Arquipélago das Anavilhanas, Novo Airão Municipality; MZUSP 31099, 1, rio Negro, lago de ilha, Barcelos Municipality, $00^{\circ} 58^{\prime} \mathrm{S} 62^{\circ} 57^{\prime} \mathrm{W}$; Roraima: INPA 2058, 1, rio Uraricoera, Ilha de Maracá, Alto Alegre Municipality; INPA 4885, 1, rio Uraricoera, Ilha de Maracá, Furo Santa Rosa, Alto Alegre Municipality; NMW 46863, 1, rio Branco, Conceiçao. Colombia: Vichada: IAvH-P 5710, 1, río Tomo, Cumaribo, 05²2’35.1"N 6751'7.6"W; IAvH-P 5711, 3 , caño, río Tomo basin, Cumaribo, $05^{\circ} 22^{\prime} 34.6^{\prime \prime} \mathrm{N} 68^{\circ} 02^{\prime} 12.1^{\prime \prime W}$; IAvH-P 5712, 3, río Tomo, Cumaribo, 05²2’35.1"N 6751’07.6"W; IAvH-P 5728, 1, río Tomo, Cumaribo, 05²2’41.1"N 6751'07.9"W. Guyana: ANSP 39817, 2, Rupununi River; ANSP 177349, 2, Siparuni River, Blackwater camp, 0444’00"N 5859’00"W; ANSP 179142, 5, Simoni River (Rupununi Dr.), 4 stations along river from

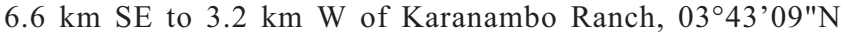
59¹5'40"W; ANSP 179143, 1, “Two Puddle Creek”(trib Rupununi River), road crossing $1.9 \mathrm{~km}$ W of Karanambo Ranch, 0345' $11^{\prime \prime} \mathrm{N}$ 59¹9’38"W; ANSP 179144, 2, Rupununi River (Essequibo Dr.), $4.6 \mathrm{~km}$ NW of village of Massara, 03 ${ }^{\circ} 55^{\prime} 34^{\prime \prime} \mathrm{N} 59^{\circ} 16^{\prime} 49^{\prime \prime} \mathrm{W}$; ANSP 179145, 1, Circle W Creek (trib Pirara River, Ireng-Takutu Dr.), 26.6 km SW of Karanambo Ranch, 03³9'14"N 59॰31'43"W; ANSP 179146, 1, Pirara River (Ireng-Takutu-Branco Dr.), 3.5 km NNW of Pirara, 0338'55"N 5941'20"W; ANSP 179146, 1, Pirara River (Ireng-Takutu-Branco Dr.), 3.5 km NNW of Pirara, 03³8' $55^{\prime \prime} \mathrm{N}$ 5941'20"W; ANSP 179628, 1, Takutu River (Branco-Negro Dr.), ca. $2.75 \mathrm{~km} \mathrm{~W}$ of Saint Ignatius, $03^{\circ} 21^{\prime} 18^{\prime \prime N} 59^{\circ} 49^{\prime} 51^{\prime \prime W}$; ANSP 180286, 1, Kuyuwini River (Essequibo Dr.), $60.6 \mathrm{~km}$ ENE of Kuyuwini Landing, 179 km SE of Lethem, 02¹1'35"N 5842'15"W; BMNH 1857.6.13.163, dry mount, holotype of Doras hancockii Valenciennes in Cuvier \& Valenciennes 1840, Demerara; USNM 377589, 2, Marlcapa Creek. Venezuela: Amazonas: ANSP 161504, 1, caño Caripo, 1st Casiquiare caño ca. $5 \mathrm{~min}$. from confluence of Casiquiare and Orinoco, $03^{\circ} 06^{\prime} \mathrm{N} 65^{\circ} 50^{\prime} \mathrm{W}$; ANSP 161505 , 1 , outflow stream from series of morichals ca. $5.0 \mathrm{~km}$ from mouth of río Pamoni, $02^{\circ} 48^{\prime} \mathrm{N} 65^{\circ} 53^{\prime} \mathrm{W}$; ANSP 161506 , 1, caño of río Casiquiare ca. $22 \mathrm{~km}$ downstream from mouth of río Pamoni (E side), $02^{\circ} 47^{\prime} \mathrm{N}$ $66^{\circ} 03^{\prime} \mathrm{W}$; ANSP 162763,17 , backwater of río Orinoco behind sand playa ca. 30 minutes upstream from Isla Temblador, $03^{\circ} 04^{\prime} \mathrm{N}$ $66^{\circ} 28^{\prime} \mathrm{W}$; ANSP 165810, 12, caño (Orinoco Dr.) separating island 
and playa just downstream from Quiratare, $02^{\circ} 59^{\prime} \mathrm{N} 66^{\circ} 04^{\prime} \mathrm{W}$; ANSP 182236, 2, small trib to río Manapiare (Ventuari-Orinoco Dr.), near village Alto Guaviarito, $17.5 \mathrm{~km}$ NW San Juan de Manapiare, $05^{\circ} 26^{\prime} 29^{\prime \prime} \mathrm{N} 66^{\circ} 09^{\prime} 47^{\prime \prime} \mathrm{W}$; ANSP 182249, 2, río Manapiare (Ventuari-Orinoco Dr.), 14 km NW of San Juan de Manapiare, $05^{\circ} 26^{\prime} 13^{\prime \prime} \mathrm{N} 66^{\circ} 06^{\prime} 51^{\prime \prime} \mathrm{W}$; ANSP 182275 , 1 , mouth of trib to río Manapiare and associated backwater (Ventuari-Orinoco Dr.), $17.5 \mathrm{~km} \mathrm{NW}$ of San Juan de Manapiare, 05²6’24"N

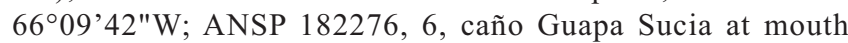
(Atabapo-Orinoco Dr.), $2.27 \mathrm{~km} \mathrm{~N}$ of San Fernando de Atabapo, 0401'52"N 6741'51"W; ANSP 182795, 1, río Ventuari (Orinoco Dr.), raudales Tencua (rapids), $56 \mathrm{~km}$ ESE of San Juan de Manapiare, $05^{\circ} 02^{\prime} 59^{\prime \prime N} 65^{\circ} 37^{\prime} 38^{\prime \prime W}$; ANSP 182845, 4, río Ventuari (Orinoco Dr.), at mouth of caño Camqui, $145 \mathrm{~km}$ NNE of Macuruco, $189 \mathrm{~km}$ NE of San Fernando de Atabapo, 0503'21"N 66 19'39"W; ANSP 185205 , 1, río Ventuari (Orinoco Dr.), ca. 20 airmiles east-northeast of confluence with río Orinoco, near fish market, $04^{\circ} 04^{\prime} 32^{\prime \prime} \mathrm{N}$ 6653’34"W; USNM 163201, 1, río Atabapo near San Fernando de Atabapo.

Platydoras sp. (small eye).-Brazil: Mato Grosso: ANSP 187052 [ex. MZUSP 86217], 1, trib. Rio Araguaia, Corixo da Saudade (Corixinho), $25 \mathrm{~km}$ northwest of Cocalinho, 14²17'20"S 51 ${ }^{\circ} 09^{\prime} 12^{\prime \prime W}$; MZUSP 86217, 3, same data as ANSP 187052; USNM 320041, 3, trib Batovi River (upper Xingu Dr.), Waura indian village. Pará: INPA 5121, 4, rio Tocantins, lago grande, Itupiranga Municipality, $05^{\circ} 09^{\prime} \mathrm{S} 49^{\circ} 20^{\prime} \mathrm{W}$.

Platydoras sp. (large eye).-Brazil: Mato Grosso: MZUSP 86993, 1 , rio Culuene, trib Xingu, Canarana/Gaúcha do Norte Municipalities, 13³0'52"S 5305’34"W; MZUSP 87029, 1, rio Corisevo, trib Xingu, Porto do Vitório, near riberão Kevuaieli, Gaúcha do Norte Municipality, $13^{\circ} 02^{\prime} 05^{\prime \prime S ~ 5325 ' 19 " W, ~} 19$ Oct 2004; Pará: ANSP 187053 [ex. MZUSP 36859], 2, rio Xingu (Amazonas Dr.), cachoeira do Espelho, Altamira Municipality, 0348'S 52³2'W; MZUSP 36859, 1, same data as ANSP 187053; MHNG 2586.4, 2, rio Tapajos, downstream of Itaituba; MZUSP 62671, 1, rio Tapajos, São Luis Municipality, $04^{\circ} 27^{\prime} \mathrm{S} 56^{\circ} 15^{\prime} \mathrm{W}, 4-5$; Tocantins: UNT 155 , 1, rio Santa Tereza, Água Branca farm, Peixe Municipality, $11^{\circ} 48^{\prime} 07^{\prime \prime S} 48^{\circ} 38^{\prime} 21^{\prime \prime W}$.

\section{Acknowledgments}

The senior authors (NMP, JCG) are indebted to Heraldo A. Britski and José L. Figueiredo (MZUSP), the late Haroldo Travassos and Gustavo A. Nunan (MNRJ), Marie-Louise Bauchot and Martine Desoutter (MNHN), Barbara Herzig (NMW) and Soraya Barrera (CBF) for loan of specimens; the Conselho Nacional de Desenvolvimento Científico e Tecnológico (CNPq) provided funds and a continuing grant for JCG. For loans of specimens, hospitality during visits, and help in the field the junior authors (MAH, MHSP) are indebted to Carlos Agostinho, Jonathan Armbruster, Eduardo Baena, José Birindelli, Juan Bogotá Gregory, Barbara Brown, Paulo Buckup, Brooks Burr, David Catania, Raphael Covain, Margarete de Lucena, William Eschmeyer, Michael Hardman, Tomio Iwamoto, Flávio Lima, Paulo Lucinda, Nathan Lujan, James Maclaine, Javier Maldonado, Christine Mayer, Naércio Menezes, Ernst Mikschi, Jan Mol, Cristiano Moreira, Sonia
Fisch-Muller, Douglas Nelson, André Netto-Ferreira, Hernán Ortega, Osvaldo Oyakawa, Lawrence Page, Patrice Pruvost, Lúcia Rapp Py-Daniel, Sandra Raredon, Roberto Reis, Rob Robins, Mary Anne Rogers, Cristina Sabaj Pérez, Scott Schaefer, Jeff Stewart, Kevin Swagel, Helmut Wellendorf, Dave Werneke, Philip Willink and especially Leandro Melo de Sousa. Study supported in part by the All Catfish Species Inventory (NSF DEB-0315963) including subaward 05-48 to MAH.

\section{Literature Cited}

Bleeker, P. 1862-1863. Atlas Ichthyologique des Indes Orientales Néêrlandaises, Publié sous les Auspices du Gouvernement Colonial Néêrlandais. Tome II.- Siluroïdes, Chacoïdes et Hétérobranchoïdes, Amsterdam. 112p., pls. 49-101. [Issued in installments. Text pages $1-32$ and plates $49-72$ date to 1862 ; pages 33-112 and plates 73-101 date to 1863. See Boeseman (1983: 4) for details.]

Bleeker, P. 1863. Sur quelques genres nouveaux du groupe des Doras. Nederlandsch Tijdschrift voor de Dierkunde, 1: 10-18.

Bleeker, P. 1864. Description des espèces de Silures de Suriname, conservées aux Musées de Leide et d'Amsterdam. Natuurkundige Verhandelingen van de Hollandsche Maatschappij der Wetenschappen te Haarlem (Ser. 2), 20: 1-104.

Boeseman, M. 1983. Introduction. Pp. 1-12. In: P. Bleeker. Atlas Ichthyologique des Indes Orientales Néêrlandaises; Plates Originally Prepared for Planned Tomes XI-XIV, Smithsonian Institution Press, Washington.

Böhlke, J. E. 1970. A new species of the doradid catfish genus Leptodoras, with comments on related forms. Proceedings of the California Academy of Sciences, Series 2, 38: 53-61.

Cuvier, G. \& A. Valenciennes. 1840. Histoire Naturelle des Poissons. Tome Quinzième. Suite du Livre Dix-septième. Siluroïdes. Ch. Pitois \& Ve Levrault, Paris \& Strasbourg, xxxi +540p.

Eigenmann, C. H. \& R. S. Eigenmann. 1890. A revision of the South American Nematognathi or cat-fishes. Occasional Papers of the California Academy of Sciences, 1: 1-508.

Eigenmann, C. H. \& R. S. Eigenmann. 1891. A catalogue of the fresh-water fishes of South America. Proceedings of the United States National Museum, 14:1-81.

Ferraris, Jr., C. J. 2007. Checklist of catfishes, recent and fossil (Osteichthyes: Siluriformes), and catalogue of siluriform primary types. Zootaxa, 1418:1-628.

Fowler, H. W. 1941. A collection of fresh-water fishes obtained in Eastern Brazil by Dr. Rodolpho von Ihering. Proceedings of the Academy of Natural Sciences of Philadelphia, 93: 123-199.

Fowler, H. W. 1951. Os peixes de água doce do Brasil. Arquivos de Zoologia do Estado de São Paulo, 6: 405-625.

Gray, J. E. 1854. Catalogue of Fish Collected and Described by Laurence Theodore Gronow, now in the British Museum. British Museum, London, 196p.

Gronovius, L. T. 1756. Museum Ichthyologicum, Tomus Secundus, Sistens Piscium Indigenorum \& Nonnullorum Exoticorum, quorum Maximum pars in Museo Laurenti Theodori Gronovii, J. U. D. Adservantar, Descriptiones, Ordine Systematico; Accedunt Nonnullorum Exoticorum Piscium Icones, Aeri Incisae. Theodorum Haak, Lugduni-Batavorum, 88p.

Günther, A. 1868a. Diagnoses of some new freshwater fishes from Surinam and Brazil, in the collection of the British Museum. 
Annals and Magazine of Natural History (Ser. 4), 1: 475-481. Günther, A. 1868b. Descriptions of freshwater fishes from Surinam and Brazil. Proceedings of the Zoological Society of London, 1868: 229-247.

Hancock, J. 1828. Notes on some species of fishes and reptiles, from Demerara, presented to the Zoological Society by John Hancock, Esq., corr. memb. Zool. Soc. In a letter addressed to the secretary of the Society. Zoological Journal, London, 4: 240-247.

Kner, R. 1855. Ichthyologische Beiträge. Sitzungsberichte der Kaiserlichen Akademie der Wissenschaften, MathematischNaturwissenschaftlichen Classe, Wien, 17: 92-162.

Linnaeus, C. 1758. Systema Naturae Sive Regna Tria Naturae, Secundum Classes, Ordines, Genera, Species, cum Characteribus, Differentiis, Synonymis, Locis. Tomus I. Editio decima, reformata. Holmiae, $824 \mathrm{p}$.

Menezes, R. S. \& M. F. Menezes. 1948. Alimentação de "graviola", "Platydoras costatus" (Linnaeus) da lagoa de Nazaré, Piauí (Actinopterygii, Doradidae). Revista Brasileira de Biologia, 8(2): 255-260.

Piorski, N. M., 1997. Estudo Taxonômico do Gênero Platydoras Bleeker, 1863 (Siluriformes, Doradidae). Unpublished M.Sc. Dissertation, Instituto de Biociências de Rio Claro, Universidade Estadual Paulista. 81p.

Piorski, N. M. 1999. Diferenciação morfométrica entre as espécies Platydoras costatus (Linnaeus, 1766) e P. armatulus (Cuvier \& Valenciennes, 1840) (Pisces; Siluriformes; Doradidae). Comunicações do Museu de Ciências e Tecnologia da PUCRS - Série Zoologia, 12: 19-30.
Sabaj, M. H. \& C. J. Ferraris, Jr. 2003. Family Doradidae, Pp. 456479. In: R. E. Reis, S. O. Kullander \& C. J. Ferraris, Jr. (Eds.). Check List of the Freshwater Fishes of South and Central America. Porto Alegre, Edipucrs, 729p.

Soares, E. C. 2005. Peixes do Mearim. São Luís, Instituto Geia, 142p.

Strauss, R. E. \& F. L. Bookstein. 1982. The truss: body form reconstructions in morphometrics. Systematic Zoology, 31(2): 113-135.

Walbaum, J. J. 1792. Petri Artedi Sueci Genera Piscium. In Quibus Systema Totum Ichthyologiae Proponitur cum Classibus, Ordinibus, Generum Characteribus, Specierum Differentiis, Observationibus Plurimis. Redactis Speciebus 242 ad Genera 52. Ichthyologiae, pars iii. Grypeswaldiae, impensis A. F. Röse, $723 \mathrm{p}$.

Wheeler, A. C. 1958. The Gronovius fish collection: a catalogue and historical account. Bulletin of the British Museum (Natural History), Historical Series, 1(5): 187-249.

Wheeler, A. C. 1985. The Linnaean fish collection in the Linnean Society of London. Zoological Journal of the Linnean Society, 84: 1-76.

Wheeler, A. C. 1989. Further notes on the fishes from the collection of Laurens Theodore Gronovius (1730-1777). Zoological Journal of the Linnean Society, 95: 205-218.

Accepted September, 2008 Published September 30, 2008 